Objectives, Methods, and

Environment-Gila River

Phreatophyte Project,

Graham County, Arizona

GEOLOGICAL SURVEY PROFESSIONAL PAPER 655-A 
OBJECTIVES, METHODS, AND ENVIRONMENT GILA RIVER PHREATOPHYTE PROJECT, GRAHAM COUNTY, ARIZONA 

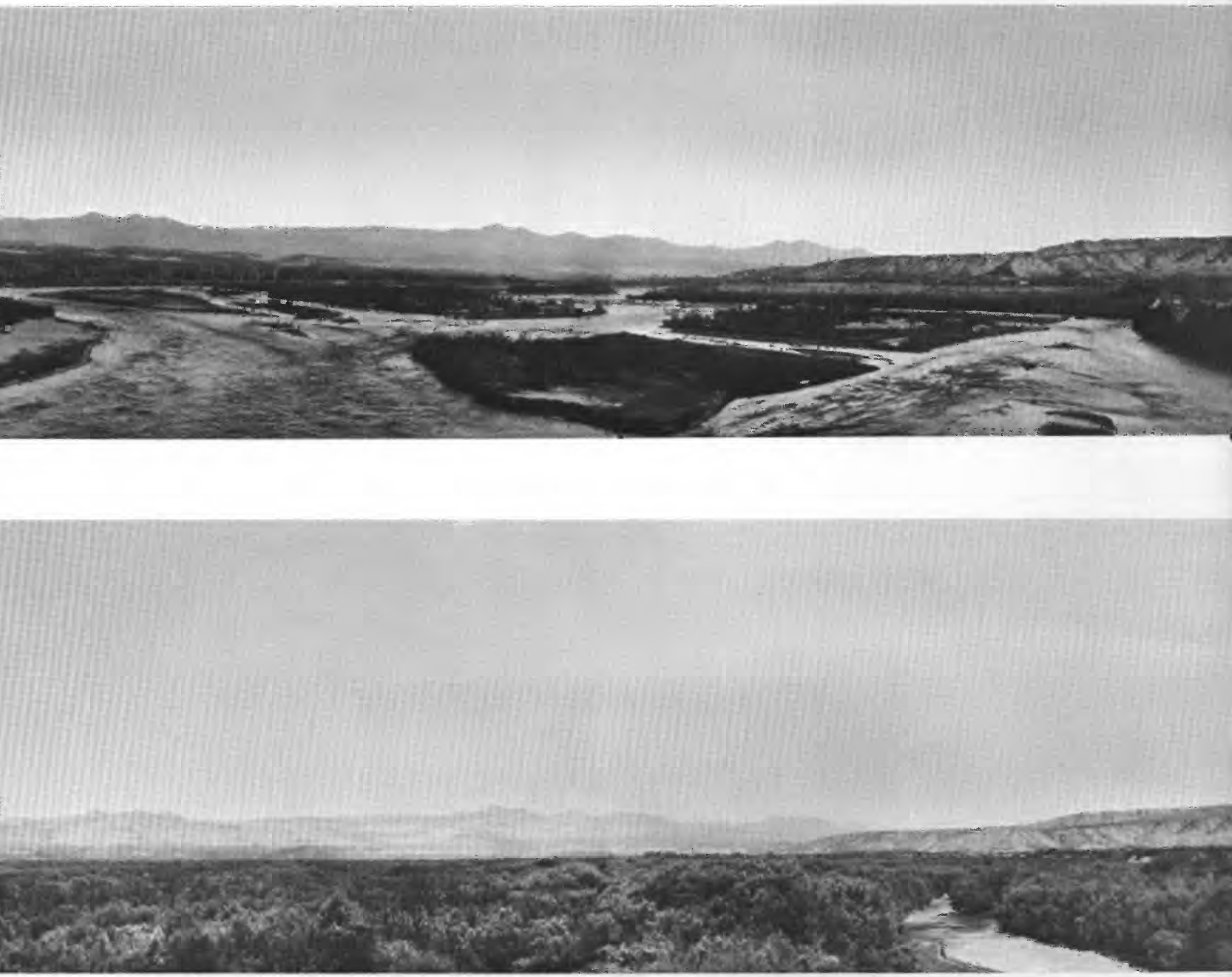

View upstream from the railroad bridge near Calva, Ariz. showing encroachment of the Gila River flood plain by saltcedar between 1932 and 1964. 


\section{Objectives, Methods, and}

\section{Environment-Gila River}

Phreatophyte Project,

Graham County, Arizona

By R. C. CULLER AND OTHERS

GILA RIVER PHREATOPHYTE PROJECT

GEOLOGICAL SURVEY PROFESSIONAL PAPER 655-A

Contributors to this report are D. E. Burkham, M. R. Collings, R. C. Culler, E. S. Davidson, R. L. Laney, O. E. Leppanen, I. S. McQueen, N. C. Matalas, R. F. Miller, R. M. Myrick, R. M. Turner, and W. G. Weist, Jr.

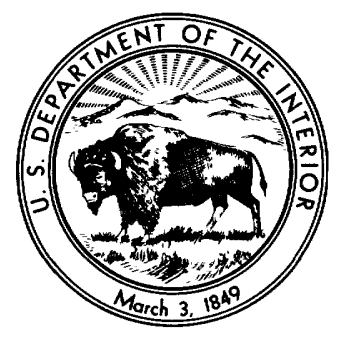




\section{UNITED STATES DEPARTMENT OF THE INTERIOR}

WALTER J. HIGKEL, Secretary

\section{GEOLOGICAL SURVEY}

William T. Pecora, Director

For sale by the Superintendent of Documents, U.S. Government Printing Office Washington, D.C. 20402 - Price 45 cents (paper cover) 


\section{PREFACE}

This report is the first of a series of professional papers describing the hydrologic studies associated with the Gila River Phreatophyte Project. The project plan is described in the report, including the details of observation. A sequence of fact finding, estimation, and decision is necessary in planning a project of this scope.

First a study was made of the available information. Specific objectives were then defined, and the hydrologic problem was identified. Methods of measurement were investigated and a primary method was selected. The data requirements and statistical problems involved in the application of this method were then considered. A site was selected and the hydrologic characteristics investigated. Methods of data collection were determined and the project area was instrumented.

The organization of this report follows the general sequence used in planning the project. A brief description of the facts considered and analyzed is presented to explain the reasons for making the planning decisions. The advice and assistance of many scientists were used in planning the project. The contributors to this report are the persons having the primary responsibility for making decisions concerning the planning and for subsequent reporting of results on the various phases of the project. 


\section{CONTENTS}

Preface

Abstract.

Introduction, by R. C. Culler.

Objective.

Evapotranspiration: Its measurement and variability by 0 . E. Leppanen . . . .

Introduction . . . . . . .

Evapotranspiration variations ...................

Evapotranspiration measurement. . . . . . . . . .

Some aspects of statistical analysis of the water-budget method, by N. C. Matalas.

Introduction . .

Water-budget period

Experimental design and analysis...............

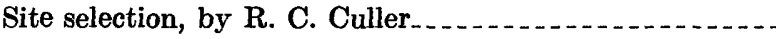

Geohydrology, by E. S. Davidson and W. G. Weist, Jr--

Introduction.

Basin-fill deposits.................................

Flood-plain and terrace alluvium

Climate, by M. R. Collings

Characteristics

Measurement of precipitation

Surface water, by D. E. Burkham

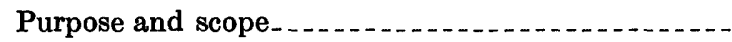

Physical description of the Gila River drainage area.

Gila River drainage area above the study reach

Tributaries adjacent to the study reach........

Gila River through the study reach

\begin{tabular}{|c|c|}
\hline Page & Surface water, by D. E. Burkham-Continued \\
\hline $\mathbf{v}$ & Streamflow characteristics. \\
\hline A1 & Gila River \\
\hline 1 & Tributaries \\
\hline 2 & Data-collection program \\
\hline 2 & Gila River surface flow \\
\hline & Gila River near Bylas, Ariz \\
\hline 3 & Gila River at Calva, Ariz \\
\hline 3 & Gila River near Calva, Ariz_........ \\
\hline 3 & Gila River above Coolidge Dam, Ariz \\
\hline 5 & Tributary surface flow \\
\hline & Changes in the streamflow conveyance system \\
\hline 5 & Ground water, by R. M. Myrick \\
\hline 5 & Introduction \\
\hline 6 & Observation-well network \\
\hline 6 & Water-level records \\
\hline 7 & Soil-moisture observations, by R. M. Myrick \\
\hline 8 & Vegetation, by R. M. Turner \\
\hline 8 & Characteristics \\
\hline 8 & Plan of study \\
\hline 8 & Phreatophyte removal \\
\hline 10 & Revegetation \\
\hline 10 & Quality of water, by R. L. Laney \\
\hline 10 & Characteristics \\
\hline 11 & Plan of study \\
\hline 11 & Data analysis \\
\hline 12 & $\begin{array}{l}\text { Soil-moisture-energy factors influencing evapotranspira- } \\
\text { tion in riparian vegetation, by R. F. Miller and I. S. }\end{array}$ \\
\hline & $\begin{array}{l}\text { McQueen } \\
\text { The energy budget for evapotranspiration measurement, }\end{array}$ \\
\hline 12 & by $0 . \mathrm{E}$. Leppanen. \\
\hline 12 & Summary, by R. C. Culler \\
\hline 12 & eforanceo sited \\
\hline
\end{tabular}

\section{ILLUSTRATIONS}

Page

A13

13

13

14

14

14

14

14

15

15

16

16

17

17

17

19

19

20

21

21

21

21

22

22

22

23

24

Frontisprece. Photographs near Calva, Ariz., showing encroachment of the Gila River flood plain by saltcedar between 1932 and 1964 .

Figure 1. Map showing Gila River Phreatophyte Project area and instrumentation location.

2. Photograph of the central part of the project area

3. Photograph showing exposure of basin fill in the lower part of the project area

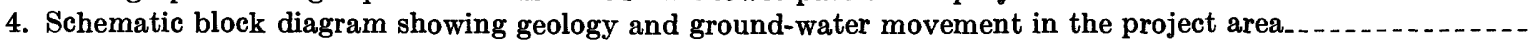
5-10. Photographs showing:

5. Lower part of project area during high water and the natural levees.

6. Log jam and sediment accumulation below section 23

7. Water-level observation well

8. Hydraulic rotary vacuum drill used to install soil-moisture wells

9. Typical observation site

10. Energy-budget station in operation at section 19 



\section{OBJECTIVES, METHODS, AND ENVIRONMENT-GILA RIVEP PHREATOPHYTE PROJECT, GRAHAM COUNTY, ARIZONA}

By R. C. CuLrer and others

\begin{abstract}
An inadequate water supply and an increasing demand for water have made conservation of water essential in the arid Southwest. One conservation method, which has been used in several places and which has been proposed for others, is replacement of phreatophytes by useful vegetation. Nonbeneficial plants infest areas of shallow ground water, such as flood plains of major rivers. Tank studies have shown that phreatophytes use more water than beneficial grass in the same location. However, many hydrologic variables in nature are not duplicated in tank studies.
\end{abstract}

The most obvious need in phreatophyte-control research is evaluation of water conservation on a flood plain typical of many areas of existing and proposed application. Hydrologic and ecologic variables must be defined by the evaluation so that the data may be applied to other sites. The Gila River Phreatophyte Project was begun in 1962 by the U.S. Geological Survey in order to make this evaluation.

The project area is a 24-kilometer (15-mile) reach of the Gila River fiood plain in the San Carlos Indian Reservation which has been divided into three subreaches. About 2,400 hectares (6,000 acres) are covered by phreatophytes, principally saltcedar and mesquite. Phreatophyte removal was started on the upper subreach in 1966 ; the middle and lower subreaches were undisturbed until 1967. The period of preclearing measurement of evapotranspiration extended from 1963 to 1966 for the upper subreach and from 1964 to 1967 for the other two subreaches. Postclearing measurement will extend to July 1972.

A water budget is being used to compute evapotranspiration as a residual. The water budget includes surface and subsurface infiow and outflow in the Gila River and its tributary infiow to the reach, precipitation on the fiood plain, and changes in ground-water storage in the saturated and unsaturated zones of the study reach. The vegetation, chemical quality of water, sedimentation, and climate also are being studied. The water budget will be the basic method of evaluation, but other methods will be applied and tested. All data are being collected for analysis by digital computer and will be subjected to rigorous statistical tests.

\section{INTRODUCTION}

By R. C. Culler

Phreatophytes are plants that depend on ground water within reach of their roots for their water supply. More than 70 species of plants have been classified as phreatophytes (Robinson, 1958, p. 1). The consumptive use of water differs greatly among species, but, in general, phreatophytes use more water than other vegetation in the same environment. The annual consumptive use by saltcedar (Tamarix pentandra Pall.), which is almost always one of the most vigorous phreatophytes, may be more than 9 acre-feet per acre (Gatewood and others, 1950, p. 137). Most phrertophytes have no marketable value as forage or timl rr. However, many conservationists consider phreatophytes desirable for the maintenance of wildlife habitat.

Phreatophytes, such as saltcedar, produce a flood hazard by choking normal channels and reducing the conveyance of floodflows. (See frontispiece.) Reduction in conveyance causes above-normal deposition of sediment in channels and on banks, creating natural levees. Overbank flows do not drain back to the channel, and the swamp that is formed creates ideal conditions for consumptive waste. Channel choking and ponding have caused problems of inflow-channel maintenance in the generally unused upstream end of reservoirs on siltladen streams. Elephant Butte Reservoir on the Rio Grande and Lake McMillan on the Pecos River in New Mexico and the San Carlos Reservoir on the Gila River in Arizona are examples.

In arid regions, such as the Southwestern United States, the possibility of converting consumptive we ste to beneficial use has aroused wide interest. It is erti- 
mated that phreatophytes cover 2.4 million hectares (6 million acres) in the Southwest (Robinson, 1952, p. 60). Phreatophyte-control measures have been applied to large areas of the Rio Grande and Pecos River flood plains in New Mexico, and proposals have been made for similar measures on extensive reaches of the lower Colorado and Gila Rivers in Arizona. The methods of control have been classified by Robinson $(1964$, p. 1) as: "(1) taking the plants away from the water (eradication, of which there are several ways); (2) taking the water away from the plants (here again there are several ways) ; and (3) substituting plants of higher beneficial use in the project area."

\section{OBJECTIVE}

Before the present project was begun, an extensive study was made of available data and of the research projects in operation or being planned on the effects of phreatophyte control. The results of this study were not published; however, Robinson's (1964) compilation of phreatophyte research is similar to the findings of the earlier study. Information is being collected by 48 research projects sponsored by 9 Federal and 21 State and local agencies and individuals (Robinson, 1964). Most of these projects involve eradication and vegetation-control methods, vegetation studies, and the measurement of evapotranspiration by evapotranspirometers; greenhouses and related experiments, and flood-plain evaluations. Only one of the 48 studies-on Cottonwood Wash in Arizona (Hendricks and others, 1960) - evaluated water salvage by removal of vegetation, in this case cottonwood and willow, from a narrow valley.

Reduction in the evapotranspiration by applying phreatophyte control offers the possibility of water salvage. The hydrologic regime of the flood plain of a major river is a complex system of which evapotranspiration is only one part. Thus, a change in evapotranspiration changes ground-water levels, relations of surface water and ground water, and soil-moisture storage and may change the chemical quality of both surface and ground water, which causes many problems in hydrologic measurements. Greater precision of measurement can be achieved with controlled experiments, such as greenhouse or evapotranspirometer studies, than by experiments under natural conditions. However, the application of data from controlled experiments to natural field conditions requires a complete understanding of all environmental variables and their interrelation in the habitat of the phreatophytes. At the present time these parameters of a flood plain of a major river, particularly one in an arid climate, are not understood. Undefined scale factors may be involved in translating the results of small-area studies to the large tracts typical of applied phreatophyte control.

The most obvious need in phreatophyte-control research is an evaluation of the water-salvage potential for a flood plain of a major river that has a dense phreatophyte cover, especially saltcedar. Such a study should be sufficiently intensive as to evaluate not only the water salvage but the hydrologic and environmental variables and any alteration of them caused by vegetation modification.

Objectives of the present project thus are summarized as follows: (1) to evaluate water salvage by phreatophyte control on a flood plain typical of areas of existing and proposed application, (2) to describe hydrologic and ecologic variables of the project ara sufficiently for extrapolation of these data to other sites, and (3) to test and develop methods for evaluating hydrologic variables in a large area.

The evaluation of water salvage can be stated in equation form as

in which

$$
C=E_{b}-E_{a}
$$

$$
\begin{gathered}
E_{b}=\text { evapotranspiration with phreatophytes, } \\
E_{a}=\text { evapotranspiration with altered vegetation } \\
\quad \text { cover, and } \\
C=\text { the water conservation or expected reduction } \\
\text { in evapotranspiration. }
\end{gathered}
$$

The measurement of evapotranspiration is thus the primary problem of this study. The methods of making these measurements are described in the following sections.

\section{PERSONNEL AND ACKNOWLEDGMENTS}

The project was planned and begun under the general supervision of Thomas Maddock, Jr., and F. E. Clarke, former chiefs of the General Hydrology Branch, and G. E. Harbeck, Jr., research hydrologist. Since 1967 the project has been under the geners.l supervision of R. W. Stallman, regional research coordinator. The study is under the direct supervision of $R$. C. Culler, project chief. Collection of records, ans.lysis of data on surface water, sedimentation, and chemical quality of water, geologic mapping, and aquifer tests are under the supervision of $\mathbf{H}$. M. Babcock, district chief, Water Resources Division, in Arizona. The authors of the different sections of this report are responsible for the specific phase of the study being described.

The cooperation and assistance given by the San Carlos Apache Indian Tribe, C. J. Rives, superintendent of the San Carlos Agency of the Bureau of Indian Affairs, and M. D. Young, general engineer for the San Carlos Irrigation Project of the Bureau of Indian Affairs are gratefully acknowledged. Removal of phreat- 
ophytes and replanting will be under the direct supervision of the Bureau of Indian Affairs.

Replacement vegetation and evapotranspiration along tributaries are being studied by the Department of Watershed Management, University of Arizona, in cooperation with the Bureau of Reclamation, Bureau of Indian Affairs, San Carlos Apache Indian Tribe, and U.S. Forest Service. Cooperation between the Department of Watershed Management and the Geological Survey includes the joint use of instrumentation and exchange of data.

\section{EVAPOTRANSPIRATION: ITS MEASUREMENT AND VARIABILITY}

By O. E. LePPANEN

\section{INTRODUGTION}

Hydrologic systems may extend some distance above and below the ground surface and may include openwater surfaces, bare-soil areas, and different kinds of vegetation. Water, as a liquid, flows into, out of, and within such systems. It also moves as vapor. When more vapor moves out of the system than comes in, there is a loss to the system, although not to the overall hydrologic cycle. Such losses are occasioned by evaporation from open water, evaporation from damp soil at or below the ground surface, and transpiration from plants. These vapor losses are categorized by the term evapotranspiration.

\section{EVAPOTRANSPIRATION VARIATIONS}

Evapotranspiration requires energy. This energy is available from various sources : direct sunlight, infrared radiation from clouds and the gases making up air, and sometimes, the heat content of the air itself. Open-water, bare-soil, and vegetated surfaces each respond differently to the sources of energy. Vegetation, especially, has a variety of responses owing to complex structural, optical, and physiological variations within and between species.

By far the most significant source of energy for vaporizing water from open-water surfaces is radiant heat, both direct sunlight and infrared sky radiation. Water bodies absorb large proportions of available direct solar energy because of the high optical transparence of their surfaces for this type of radiation. Sky radiation is of less importance, being mostly absorbed and then reradiated at the surface itself.

The amount of water lost from an open-water surface is determined mainly by the velocity and duration of wind over the surface and the dryness of the air relative to the ease with which water can be evaporated from the surface. More precisely, vapor loss is proportional to the product of wind speed times vapor deficit, the differ- ence between the saturation vapor pressure of the water surface and the partial pressure of the water already in the air. To compute the loss from water surfaces, the parameter relating the lass to wind movement and vanor deficit must be known. For shallow water this paramater can be estimated, and using measurements of wind movement and water temperatures, losses can be evaluated. These losses will be small because such water: in the project area are few. Knowing this parameter and its seasonal variation, open-water losses can be crmpared with river-basin losses in the vegetated armas.

Losses from bare soil cannot be measured readily, nor can the variables that control these losses be easily isolated. Again, radiant heat is the largest energy source for vaporizing water, but, because of the opacity of the surface, much less energy is available to act upon subsurface water. Beyond the energy necessary to vaporize water, additional energy is necessary to overcome canillary and adhesive forces in the soil.

Except after rains, there is little water-vapor los in areas of deep water table, because water is not easily available. Where the water table is shallow much vegetation grows, except in water courses. Evapotran viration from bare soil is reduced by the shading of vegetation. If the soil-surface layer becomes bone-dry, water brought to the surface by capillarity is redused, because water cannot flow as a liquid but must diffuse as vapor through several inches of soil. High humidity near the surface owing to plant transpiration tend" to decrease soil evaporation; however, where the wrter table is shallow factors such as large surface to sub :urface temperature differences and diurnal variations in barometric pressure may result in considerable va.oor movement through porous soil. What is often called dew is in fact condensed vapor brought from below the ground surface during the night.

Dew may occur, but mostly in areas where it would be but a small part of the water balance. Dew would rost likely be deposited on the upper part of tall vegetation. In the other areas, even on still nights, air temperatures are usually above the dew point temperature so that dew seldom occurs. Dew, even in small amounts, may b? of considerable importance to the well-being of certain desert plants, however.

In phreatophyte areas of Southwestern United States it is likely that the lairgest losses per unit area occur in riparian areas dominated by saltcedar. Water use ranges from an estimate of $120 \mathrm{~cm}$ (centimeters) $(4 \mathrm{ft}$ ) per year as an average for saltcedar areas in the Western States (Robinson, 1965) to measurements of 250 $\mathrm{cm}(81 / 4 \mathrm{ft})$ per year for young saltcedar plants growing in two large tanks near Buckeye, Ariz. (van Hylckama, 1963). In 1964, water use in these tanks was 
$210 \mathrm{~cm}$ (7 ft) from April through August (T. E. A. van Hylckama, written commun., 1966). Cotton areas in the Salt River valley would have had a consumptive use of $64 \mathrm{~cm}(2 \mathrm{ft}$ ) in the same period (Blaney and Criddle, 1962). At maximum potential plant density, water use by baccharis is about $140 \mathrm{~cm}(41 / 2 \mathrm{ft})$ per year, use by mesquite is about $100 \mathrm{~cm}(31 / 4 \mathrm{ft})$, and use by saltcedar is about $225 \mathrm{~cm}(71 / 2 \mathrm{ft})$. These data apply to the flood plain of the Gila River (Gatewood and others, 1950).

Determination of water use in plant-covered areas is complicated by the differences between species as well as differences between plants within a species. Vegetation cannot be analyzed in the same fashion as open water and bare soil because it responds differently to changing winds, differences in constituents of the ambient air, the heat-radiation spectrum, water quality, water presence, daily temperature ranges, and average temperatures.

Most plants that use much water in summer are deciduous. As average temperature decreases they drop their leaves, and water use is negligible. The bare, rigid branches serve only to increase wind turbulence, and they allow the wind to carry away any available water faster. As foliage returns the wind turbulence changes. Wind turbulence over leaf covered vegetation does not increase with velocity in the same proportion as turbulence over bare soil or water. As wind velocity over vegetation increases, the boughs and branches bend, the vegetated surface becomes hydraulically smoother, and turbulence decreases. This is in contrast to a water surface where waves develop, the surface grows rougher, and turbulence increases.

Constituents of the air change in or near vegetated areas. In the heat of summer, dense thickets of saltcedar demand considerable water, but their water use can be restricted by a lessened ability of the wind to carry away transpired water vapor. Photosynthesis requires carbon dioxide, and unless the wind can supply it as required, plant activity may be restricted.

Leaf and branch surfaces are selective in their response to direct solar radiation (Gates, 1965). Not much is known about this among the many species of plants, but certainly they cannot be as uniformly treated as bare-soil and open-water surfaces.

Water quality, particularly the amount of salt dissolved in water, affects water use by plants. Data pertaining to plants in the project area are generally lacking, but transpiration rates may change markedly with changing salinity. Of three sets of paired tanks containing saltcedar, those that were flushed relatively free of salt before the growing season used about $50 \mathrm{~cm}$ $(1.6 \mathrm{ft})$ more water during the growing season than those that were not flushed (T. E. A. van Hy]ckama, written commun., 1966). The average use of all tanks, located near Buckeye, Ariz., was about $150 \mathrm{~cm}(5 \mathrm{ft}$ ) during the experimental period, April through August 1965. Thus, water use by saltcedar may depend on the degree to which floods and rains have leached soil salts or have freshened ground water.

Losses from open water and usually from soil are not affected greatly by water quality except under extreme conditions, such as local ponding, where salinit"r could increase greatly owing to evaporation until the saturation vapor pressure at the water surface would be significantly affected.

When plant roots cannot draw moisture from the soil, transpiration does not exist. This situation may occur during a general drought or during a local drought largely caused by the plants themselves. Small quantities of moisture may still be lost from the soil, however, particularly near the surface. As water available to plants increases from floods, rains, capillary flow, or from a change in ground-water level, water use increases. When there is no limitation on the water supply, plants use water freely; the use rate depends on how much water is needed to keep leaf surfaces cool. Under severe conditions imposed by a hot des?rt sun, hot dry air, and considerable wind, the plants may not be able to supply water to their leaves at a rate s"fficient to keep them cool because of physiological limitations. The situation becomes the same as if the roots could not draw moisture; the plants wilt, and water use docreases rapidly. Most hot-weather species are adapted to this condition and suffer no permanent damage.

For areas covered by saltcedar a definite relation between water use and depth to the water has been shown by van Hylckama (1963) and a similar relation for other species is probable. How much of the increase in evapotranspiration with decreasing depth to water table is evaporation and how much is transpiration is not known. T. E. A. van Hylckama (1963) states; on the basis of winter observations, that the increase is mainly due to evaporation from the soil in the tanks planted with saltcedar. Near van Hylckama's study area, however, pumping has lowered the water table constantly, and saltcedars that were flourishing when the strdy was begun are now dead. This is an extreme example of dependency on depth to water; in contrast, in the San Carlos Reservoir area there are 26-year-old stands of poorly developed but growing saltcedar whose roots have not been near the water table since they wrre seedlings. These plants, which began growing when the reservoir was at its highest stage, have apparently become adapted to a nonphreatophytic existenco. 
At the other extreme is vegetation that has been inundated by water for considerable periods and dies because respiratory processes involving the exchange of carbon dioxide and oxygen gases in the roots are no longer possible.

\section{EVAPOTRANSPIRATION MEASUREMENT}

Three methods of measuring evapotranspiration in a large area of heterogeneous vegetation, bare-soil, and open-water surfaces are described here. They are: (1) the water-budget method, (2) the heat-energy budget method, and (3) the mass-transfer method.

The water-budget method of computing evapotranspiration requires that all flow of water as a liquid into and out of the hydrologic system be measured. Any unbalance in the budget results from the escape of water vapor from the system. A water budget requires careful measurements to avoid obscuring the evapotranspiration term with measurement errors of the other budget terms.

A heat-energy budget has a singular advantage; the evapotranspiration term is numerically multiplied by the amount of heat necessary to change liquid to vapor. This weighting factor has a value of about 585 per gram of water when working in the centimeter-gram-second system. Relatively large errors can thus be tolerated in the measured terms of the heat-energy budget.

The energy budget has disadvantages also. With present methods it can only be applied to areas with fairly homogeneous vegetation and soil-moisture conditions. It is an analytical approach and requires careful instrumentation, considerable computation, and much data to yield a result strictly applicable to one spot only. How this result, together with others from different locations, can be applied to a large area remains to be determined.

The mass-transfer approach, which deals with water after it has become vapor, has an inherent attractiveness when one realizes how much water is actually moved. One acre of saltcedar may transfer as much as 40 metric tons (44 short tons) of vapor into the atmosphere in 1 day. But because the water moves in such diffuse form and because of the vagaries of air currents, theoretical and instrumental problems are formidable. The most comprehensive application of mass-transfer theory would be to monitor vapor flux at altitudes considerably above the project area where vapor flows from diverse sources have mixed. Unfortunately, a unified theory that uses economically feasible field data is not available at this time; however, research in this area is continuing.

Other methods exist for estimation of evapotranspiration that are usually grouped together and are called empirical approaches. Some of these methods rest upon sound theoretical bases, and they consist fundament. lly of devices and simplifications applied to basic therry. They are designed to avoid the complexities of direct measurement of meteorological variables. However, some of the methods have obscure, if any, theoretical bases. Because these approaches lack comprehensiveness, results are often unique to locations at which measurements and correlations to real evapotranspiration have been made. However, because of the simplicity and low cost of application of the empirical approaches, reser rch has continued in their development with varying degrees of success. A good example is the application of data from U.S. Weather Bureau class A evaporation pans to estimate evaporation from lakes and evapotranspiration from vegetated areas.

\section{SOME ASPECTS OF STATISTICAL ANALYSTS OF THE WATER-BUDGET METHOD}

\section{By N. C. Matalas \\ INTRODUCTION}

Phreatophyte control involves the removal of the phreatophytes and replacement by beneficial grasses. Phreatophytes, dominantly saltcedar and mesquite, are being replaced by grasses that will provide grazing for cattle. As previously stated, if $E_{b}$ and $E_{a}$ denote moasures of evapotranspiration before and after vegetation change, respectively, then

$$
C=E_{b}-E_{a}
$$

is the resulting change in evapotranspiration.

Evapotranspiration is determined by means of a water budget defined by

$$
e=\sum_{j=1}^{8} X_{j},
$$

where the components $x_{1}, \ldots, x_{8}$ denote (1) surface inflow in the Gila River, (2) surface inflow from tributaries, (3) subsurface inflow in the alluvium of the river and its tributaries, (4) possible artesian inflow f:om underlying geologic formations, (5) surface outflow in the river, (6) subsurface outflow in the alluvium, (7) precipitation on the flood plain, and (8) change in moisture storage, respectively.

To evaluate equation 1 , the time periods $T_{b}$ and $T_{a}$, before and after modification of vegetation, respectively, are subdivided into $N_{b}$ and $N_{a}$ time increments, each of length $\Delta t$ (water-budget period), so that

$$
\begin{aligned}
T_{b} & =N_{b} \Delta t \\
T_{a} & =N_{a} \Delta t
\end{aligned}
$$


For each $\Delta t$, evapotranspiration is determined by the water budget, equation 2 , which is now defined as

$$
\begin{aligned}
e_{b_{i}} & =\sum_{j=1}^{8} X_{b_{i j}} ; i=1, \ldots, N_{b} \\
e_{a_{i}} & =\sum_{j=1}^{8} X_{a_{i j}} ; i=1, \ldots, N_{a}
\end{aligned}
$$

for before and after vegetation change, respectively.

The measures of evapotranspiration, $E_{b}$ and $E_{a}$, are defined as means of the $e_{b}$ 's and $e_{a}$ 's for all or part of the $\Delta t$ 's. In the following paragraphs, a brief description is given of the sampling problems that must be considered in estimating the $e$ 's and the general statistical approach for evaluating $C$ is outlined.

\section{WATER-BUDGET PERIOD}

Several factors must be considered in selecting the water-budget period, $\Delta t$, among which the more pertinent are the redundancy in information from one period to the next, the magnitudes of the measurement errors associated with $x_{1}, \ldots, x_{s}$, and the time and cost involved in data collection and processing. With respect to these factors, $\Delta t$ should be sufficiently small; consequently, $N_{b}$ and $N_{a}$ should be large in order to provide reliable estimates of $E_{b}$ and $E_{a}$.

Some of the water-budget components such as surface inflow are recorded continuously; thus, they can be determined for any selected period $\Delta t$. Others, however, such as the change in moisture storage, $x_{8}$, can be determined only for a finite period, $\Delta u$, where $\Delta u$ corresponds to the time interval between measurements at the sampling site. In the instance of $x_{8}$, numerous soil-moisture holes are distributed throughout the project area. If the change in soil moisture for the period, $\Delta u$, can be related to the continuously recorded fluctuations in the water table, then this soil-moisture change can be reevaluated to correspond to any predetermined water-budget period, $\Delta t$.

Observations of $x_{1}, \ldots, x_{8}$ are subject to measurement errors, the magnitudes of which vary among the components. Because these errors also tend to vary directly with the magnitudes of $x_{1}, \ldots, x_{8}$, the errors vary seasonally. If the total error, sampling plus measurement, is reduced, then a more reliable evaluation of $C$ is possible. Consequently, the observations of $e$ for those $\Delta t$ 's that correspond to periods of large storms may be neglected. This, however, reduces the total number of observations, which in turn increases the sampling errors.

Sampling errors vary inversely with the total number of observations. If $\Delta t$ is small, then $N_{b}$ and $N_{a}$ are large; however, the values of $e$ for successive $\Delta t$ 's would be highly serially correlated. Serial correlation implies a redundancy of information from one $\Delta t$ to th? next, and so the sampling errors vary inversely with $N_{b}{ }^{\prime}<N_{b}$ and $N_{a}{ }^{\prime}<N_{a}$, where $N_{b}{ }^{\prime}$ and $N_{a}{ }^{\prime}$ are functions of their serial correlation and represent the effective number of observations before and after vegetation change for $e$ 's independently distributed among the $\Delta t$ 's. The larger the serial correlation is, the smaller are $N_{b}{ }^{\prime}$ and $N_{a}{ }^{\prime}$ relative to $N_{b}$ and $N_{a}$, respectively.

Part of the serial correlation is due to the stochastic nature of the $e$ 's and the remaining part is due to seasonal trends. If $\Delta t$ is taken to be sufficiently large so as to coincide with the annual cycle, or if evapotranspiration is defined as an annual value ( $e$ summed over an appropriate number of $\Delta t ' s)$, then the seasonal trends are absent, and the serial correlation is due to the stochastic nature of evapotranspiration. For small $\Delta t$, the seasonal trends must be defined and removel from the values of $e$ for each $\Delta t$.

\section{EXPERIMENTAL DESIGN AND ANALYSIS}

Consider a project area divided into three subreaches which are subdivided into five sections; the measures of evapotranspiration for the $m$ th section in the $k$ th subreach are denoted by $E_{b_{k m}}$ and $E_{a_{k m}}$ for before and after vegetation change, respectively, where $k=1,2,3$, and $m=1, \ldots, 5$. Before the change of vegetation, the quantities $E_{b_{k m}}$ are to be investigated to determine if differences among them are significant. The differences, if significant, must be explained in terms of such factors as vegetation density, quality of water, and depth to ground water. Quantitative and qualitative measures of plant density require c'sailed mapping of the reach; quality of water and depth to water must be determined at a sufficient number of points to obtain reliable spatial estimates by maans of weighted averages of the point estimates.

Seasonal trends, if present, must be removed from the estimates of the different factors before tl 9 estimates are related to trend-free values of evapotranspiration. Unless these trends are removed, variations in evapotranspiration cannot be assessed in term 8 of the explanatory factors because the total period of ohservation, before and after vegetation modification, may not be long enough to include "average" climatic conditions.

To remove seasonal trends from plant density would require far more detailed measurement of the vegetation than seems feasible or possible at this time. Nevertheless, despite the number of plants, there is little or no transpiration during the nongrowing seasc $n$, and plant density may, therefore, be considered zero. During the growing season plant density may be definod as a single value for each subreach of the study area. These 
values may then be used to evaluate variations of evapotranspiration among the subreaches.

An analysis of covariance may be used to assess differences among the measures of evapotranspiration before vegetation change, $E_{b_{k m}}$. In the analysis, the dependent variable is evapotranspiration and the independent variables are such factors as quality of water and depth to water. Basically, the data are grouped according to season, subreach, and section. Seasonal division of the data permits investigation of evapotranspiration for the growing and nongrowing seasons. The sectional division of the data is not an independent classification of the data but is a classification nested in another classification, namely, the subreach.

The data may be subdivided still further by considering left bank or right bank and, because of the well and soil-moisture-hole alignments, the proximity of the data collection site to the main channel, for example, far intermediate, or near to the main channel. This latter classification is nested in the bank location, which in turn is nested in the section.

Usually plant density decreases with distance from a stream, so that a designation of this distance indirectly takes into account, at least partly, plant density. If for any of the classifications, differences among $E_{b_{k m}}$, prove to be insignificant at some meaningful probability level, then this classification in subsequent analyses can be regarded as replication for a better determination of the experimental error.

The analysis of covariance will yield a result concerning the significance of the differences among $E_{b}$ but the reliability of this result will depend on the measurement errors. If these errors are large and if the differences among $E_{b_{k m}}$ when there are no measurement errors are small, the differences among the observed $E_{b_{k m}}$ may be masked. To overcome at least partly the effect of measurement errors, either classification of season must be dropped and only the data for the nongrowing season considered or data corresponding to $\Delta t$ 's within the growing seasons during which large storms occurred must be deleted. If the former is done, then active effect of the phreatophytes as well as the effect of plant density is lost.

This analysis focuses attention on the question of whether the size of $T_{b}$, the time period before modification of vegetation, is sufficiently large, after due consideration has been given to the effect of measurement errors, to allow for a meaningful interpretation of the differences among the $E_{b_{k m}}$. If $T_{b}$ is found to be too small, then it is unlikely that the difference between $E_{b}$ and $E_{a}$ can be reliably assessed no matter how large $T_{a}$ may be. $T_{a}$ can be arbitrarily large because once the phreatophytes are removed and replaced by grasses, the grasses will not be removed and replaced by phreatophytes except possibly by natural processes. However, $T_{a}$ is likely to be of the same order of macnitude as $T_{b}$ for practical reasons of obtaining an early assessment of the effect of vegetation change.

After the phreatophytes are removed, a brief transition period may have to be allowed to permit replacement vegetation to become established. An analysis of covariance may then be used to investigate the diff'orence between $E_{b}$ and $E_{a}$. In addition to the various classifications of the data mentioned above, another classification-before and after modification of vegetationis needed. Because it is unlikely that $T_{b}$ and $T_{a}$ will be large, climatic conditions during $T_{b}$ and $T_{a}$ may be quite different and, thus, the difference between $E_{b}$ and $E_{a}$ may be seriously affected. Consequently, $E_{b}$ and $E_{a}$ must be related not only to the factors mentioned above but to different climatic factors as well.

\section{SITE SELECTION}

\section{By R. C. CULLER}

After careful consideration of the various methods of measuring evapotranspiration previously descri $3 d$ it was decided that the water-budget method would be the most feasible. Thus, selection of a site for the phreatophyte project was based on the need for one that would meet the requirements of this method. Other methods will also be applied and tested.

The water-budget method requires that all significant movement of water in the liquid phase, either inflow or outflow, be measured with considerable accuracy; therefore, the surface discharge characteristics of the river and its tributaries were considered in selecting a site. The geologic framework of the site was also considered as it is an important factor in controlling ground-water movement, chemical quality of water, and sediment movement.

Vegetal cover, both density and species, was of prime importance in the site selection. The area of phreatophyte dominance was selected to be sufficiently larg? to make evapotranspiration significant in the water budget. Otherwise, the computation as a residual might be completely obscured by errors in hydraulic measurements. A documented history of vegetation changer on the site also was advantageous.

Phreatophyte control is of particular interest for two types of landforms - the wide naturally developed flood plain of major streams and the sediment depcsits in the upper reaches of reservoirs. Flood-plain topography, therefore, was a factor in site selection.

Land ownership also was considered. Access for installation and maintenance of equipment was essential. Owners must be amenable to uniform and consistent 
land management during the preclearing and postclearing periods.

The existence of a site that would meet all these requirements was unlikely. A request for recommendations was sent to several hydrologists in the U.S. Geological Survey who were familiar with the phreatophyte problem. A field reconnaissance was then made of recommended sites, and records describing the sites were studied. A reach of the Gila River flood plain in the San Carlos Indian Reservation more nearly met requirements than any other site. A formal agreement was made on May 28, 1962, between the U.S. Geological Survey and the San Carlos Apache Indian Tribe, with the approval of the Bureau of Indian Affairs, for the use of reservation lands for the project.

The Gila River channel improvements proposed by the U.S. Army Corps of Engineers between the Camelsback Reservoir site and the Salt River were authorized by act of Congress, Public Law 85-500, 85th Congress, July 3,1958 . These improvements include the application of phreatophyte control in the area of the Gila River Phreatophyte Project. Thus, the expensive clearing operation required to complete the hydrologic study had already been authorized.

The project area is a 24-kilometer (15-mile) reach of the Gila River flood plain extending from the highway bridge on U.S. Highway 70 near Bylas to a point $71 / 4$ kilometers (41/2 miles) above the mouth of the San Carlos River (fig. 1). The reach, divided into three subreaches, extends into the upper part of the San Carlos Reservoir so that a large area of dense saltcedar, a shallow water table, and a sediment deposit typical of the seldom-inundated part of reservoirs in arid areas might be included. The upper subreach is above the maximum water level for which the reservoir was designed. The middle subreach is mainly above the maximum reservoir water level observed since Coolidge Dam was built in 1928. The lower subreach is underlain by sediment deposited during the period of maximum reservoir water level in 1941-42. The physical, ecologic, and hydrologic characteristics of the site are described in the following sections. The central part of the project area is shown in figure 2.

\section{GEOHYDROLOGY}

By E. S. Davidson and W. G. Weist, Jr.

\section{INTRODUCTION}

The Gila River in the northwest end of the Safford basin, Arizona, lies between two mountain ranges and occupies a broad valley which is filled with more than $300 \mathrm{~m}$ (meters) (1,000 ft) of silt, sand, and gravel. Deposits are divided into basin fill and alluvium that underlies the flood plain and adjacent low terraces of the Gila River and its tributaries. The basin fill forms the bulk of the sediment in the basin, and tho upper several hundred feet has been dissected into mesas and benches that slope from the bordering mountains toward the Gila River in the central part of tr 9 basin. Alluvium fills channels incised into the basin fill along streams between the mesas and benches. Ground water and surface water drain from the highlands surrounding the Safford basin to the Gila River and j.ts associated alluvial deposits. The water thus collecter in the lowest part of the Safford basin then moves northwestward, either as streamflow in the Gila River or as flow through the alluvium.

\section{BASIN-FILL DEPOSITS}

The basin fill (Davidson, 1961) is a thick, extensive unit of flat-lying reddish-brown to light-brown silt, sand, and clay; in the northwest part of the area the fill is mostly very pale yellow to white limestone, marl, and tuff (fig. 3 ).

Water in the basin fill is under pressure and, in wells along the Gila River, rises to within a few feet of the land surface. Water levels in this fill are several feet higher than those in wells that bottom in the orerlying alluvium of the terraces and flood plain. Wells tapping the basin fill obtain water from thin sand layers and yield only a few gallons per minute.

Water in the basin fill flows toward the lower terrace and flood-plain alluvium. Because of artesian pressure in the basin fill, water may also leak upward from this unit toward the terrace and flood-plain alluvium (fig. 4.).

\section{FLOOD-PLAIN AND TERRACE ALLUVIUA*}

Terrace alluvium fills the trough cut by the Gila River into the basin fill and is exposed along low terraces on both sides of the valley. Flood-plain alluvium ras been deposited in shallower troughs cut into the terrace alluvium by the Gila River and its tributaries (fig. 4). Flood-plain alluvium along the smaller tributaries is of very limited extent and is lumped with terrace alluvium. The top of the flood-plain alluvium is 5 to $8 \mathrm{~m}$ (15 to $25 \mathrm{ft}$ ) below the top of the terrace alluvium exposed

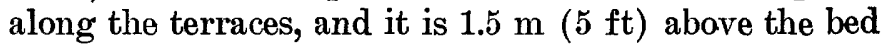
of the Gila River. Both deposits are lithologically similar and are distinguishable chiefly by toporraphic position.

The terrace and flood-plain alluvium occupying the shallow troughs cut by the Gila River range from 1,200 to $2,400 \mathrm{~m}(4,000$ to $8,000 \mathrm{ft})$ wide and up to $21 \mathrm{~m}(70 \mathrm{ft})$ thick. Along the tributaries these deposits range from 100 to $1,200 \mathrm{~m}(300$ to $4,000 \mathrm{ft})$ wide and 7 to $10 \mathrm{~m}(20$ to $30 \mathrm{ft}$ ) thick but locally may be more than $1 \mathrm{C} \mathrm{m} \mathrm{(30}$ 

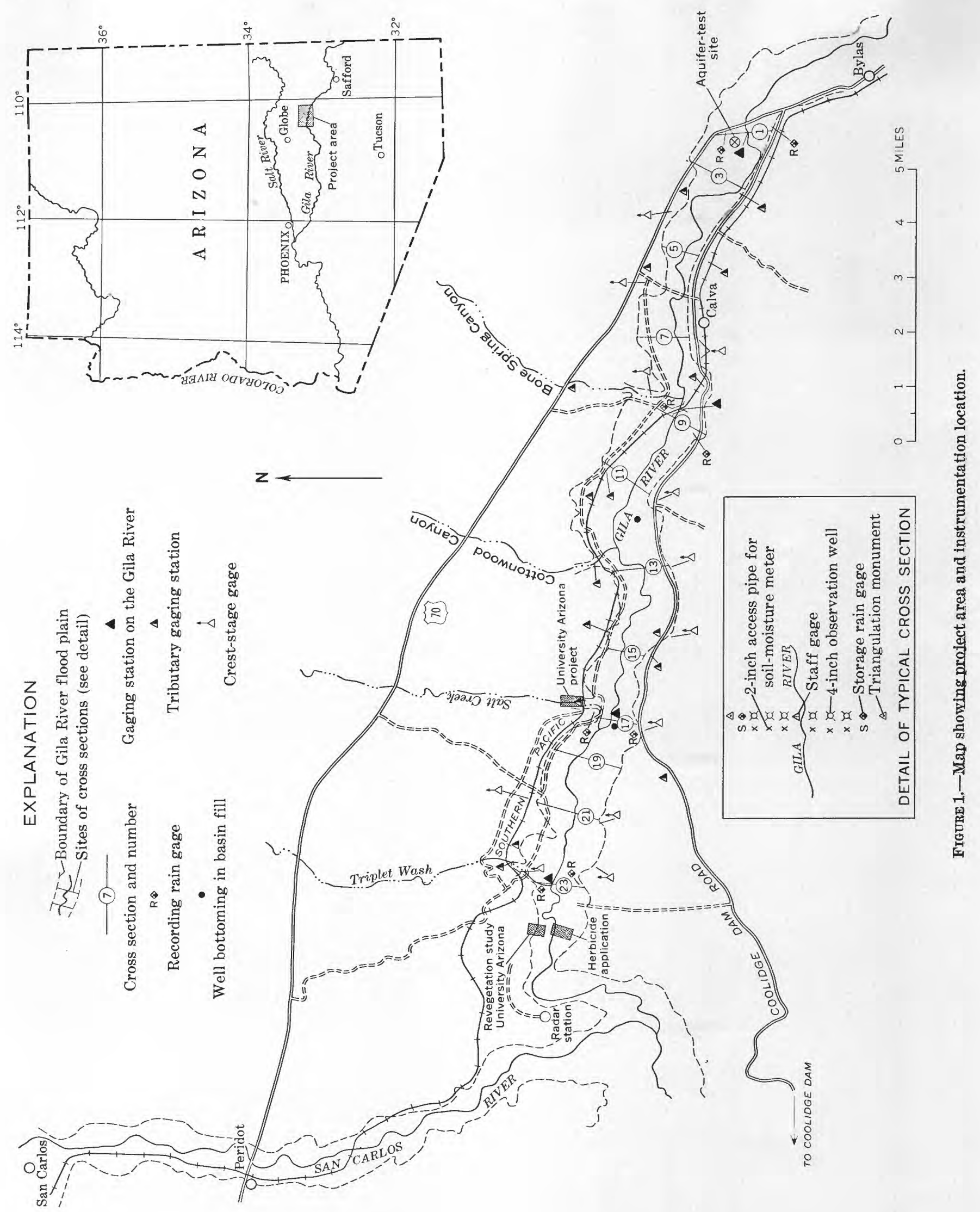


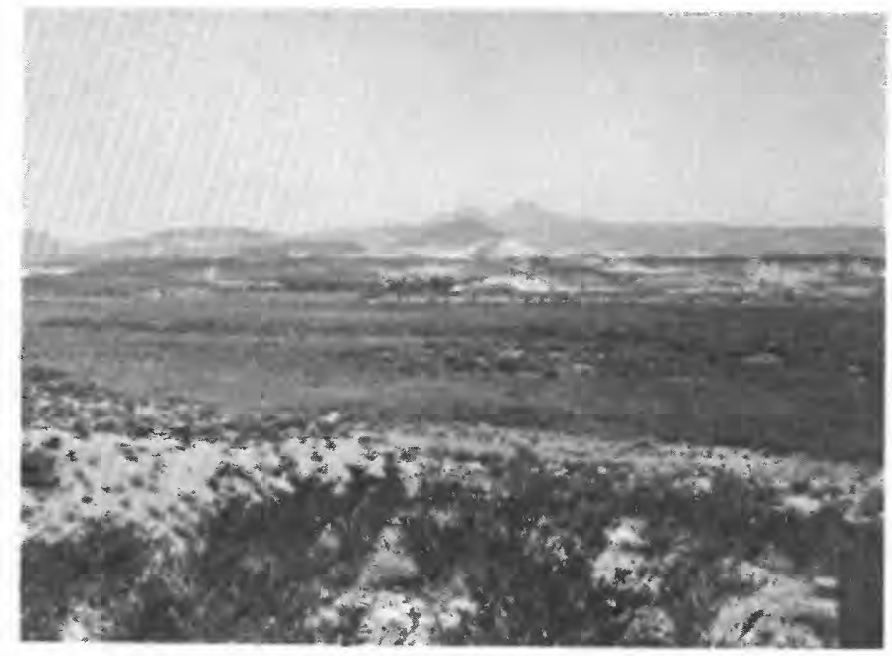

FIGURE 2.-A view of the central part of the project area looking northwestward near section 17.

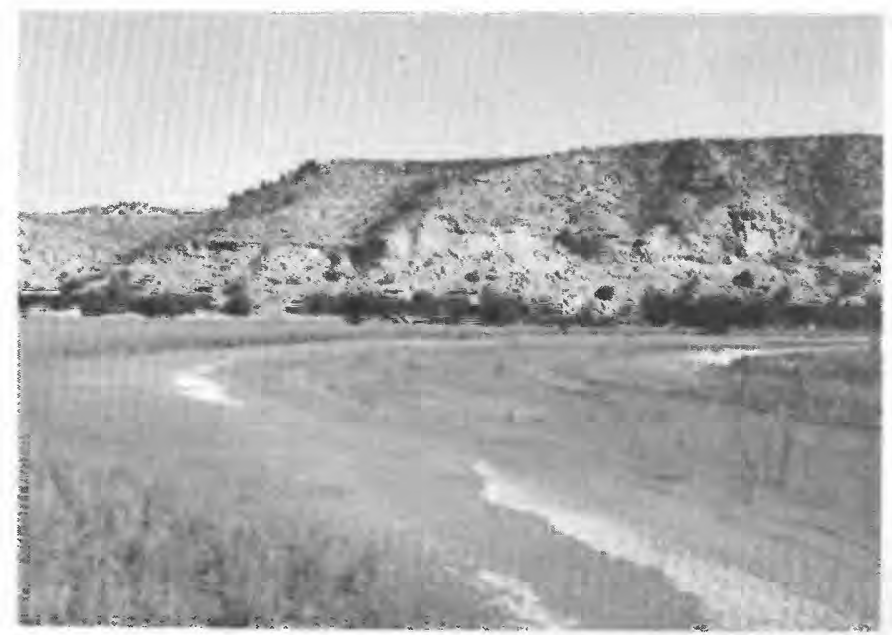

Figure 3.-Exposure of basin fill in the lower part of the project area.

ft) thick. In places, terrace alluvium is slightly more cemented than alluvium in the underlying flood plain. The bedding ranges from almost structureless horizontal thick-bedded to thickly crossbedded layers. The coarse material, lenticularity, and crossbedding or thick horizontal bedding of the terrace and flood-plain alluvium contrast markedly with the fine material and horizontal thin bedding of the basin fill.

Ground water, stored under water-table conditions, moves slowly downstream through the alluvium. The water table fluctuates in response to surface flow and generally is $1.5 \mathrm{~m}$ ( $5 \mathrm{ft}$ ) or less below the land surface near the Gila River and about $12 \mathrm{~m}$ (40 ft) deep near the surface contact between the alluvium and the basin fill. The alluvium readily accepts water from the basin fill and from the river and its tributaries. Infiltration of surface water into the alluvium is probably much larger and is certainly more variable in time than ground-water flow from the basin fill. Locally, water from the alluvium contributes to the flow of the Gila River.

\section{CLIMATE}

By M. R. Collings

\section{CHARACTERISTICS}

The project area generally has two distinct periods of precipitation-a primary one during the summer and a secondary one during the winter. Summer rains are generally the product of storms in July, August, and September and are associated with warm moist air from the Gulf of Mexico (Sellers, 1960). These storms are triggered by the combined effect of high surface temperature and orographic uplift, which sets off strong vertical air currents for convectional overturning. Showers are most frequent in the late afternoon and at night, and the driest hours are in the early afternoon. Summer rains start abruptly and usually continue for less than half an hour.

Generally, the continental anticyclone is absent in the winter and cyclonic storms produce the precipitation. Winter rain and snow at higher altitudes cause most of the sustained winter flow of the Gila River.

Partial drought is common in May and June as well as in October through mid-November.

Mean daily temperature ranges from about $0^{\circ}$ to $16^{\circ} \mathrm{C}$ $\left(32^{\circ}\right.$ to $\left.60^{\circ} \mathrm{F}\right)$ in the winter and from about $18^{\circ}$ to $38^{\circ} \mathrm{C}$ $\left(65^{\circ}\right.$ to $\left.100^{\circ} \mathrm{F}\right)$ in the summer. Mean temperature ranges from $8^{\circ} \mathrm{C}\left(46^{\circ} \mathrm{F}\right)$ in January to $31^{\circ} \mathrm{C}\left(87^{\circ} \mathrm{F}\right)$ in July (U.S. Weather Bureau, 1964). In winter, days tend to be cooler in the project area than in the surrounding area because of down slope cold-air drainage.

Average daily humidity is highest in July and August. Afternoon and night showers commonly wet the air and soil enough to raise the humidity considerably during mornings.

\section{MEASUREMENT OF PRECIPITATION}

Three types of gages are used to measure precipitation: (1) nonrecording wedge-type storage gages, (2) weighing-type recording gages, and (3) digital floatactuated recording gages. The nonrecording gages were installed at each end of the 12 cross sections shown in figure 1. Weighing-type recorders were installed on the south bank of the river at the upstream and downstream cross sections of each subreach (fig. 1, sections 1, 9, 17, and 23). Digital recording gages were installed on the north bank of the river at these same four sections. To measure precipitation adequately throughout the year, both types of recording gages are desirable, because the 

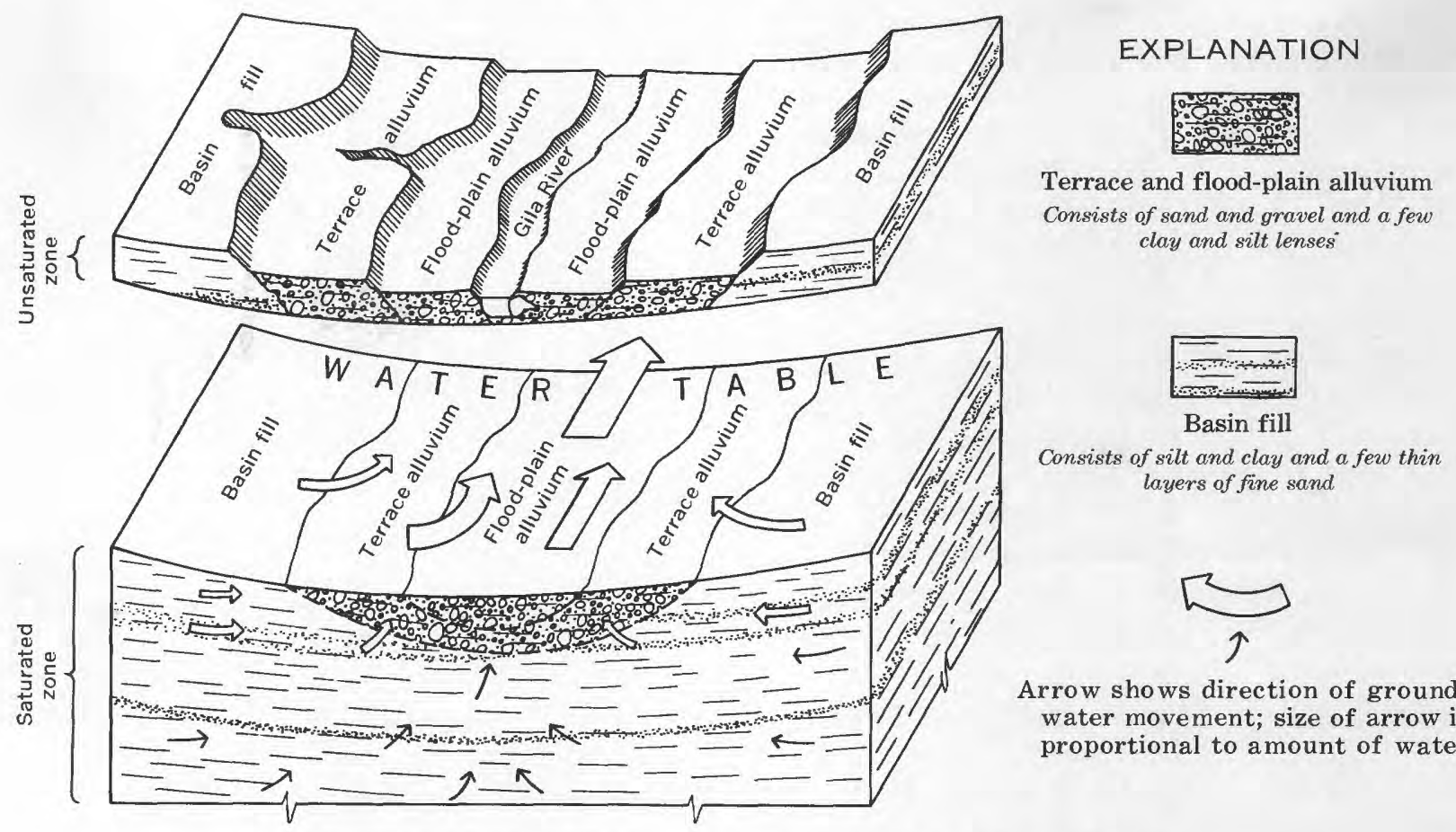

Arrow shows direction of groundwater movement; size of arrow is proportional to amount of water

Figure 4.-Geology and ground-water movement in the project area.

digital recorder does not record snowfall and the weighing-type recorder, which has a slow chart speed, does not adequately record rainfall intensities.

The fairly dense network of precipitation gages described above provides relatively comprehensive coverage of summer convective storms which typically cover only a small area at any one time. ${ }^{1}$ Most of these gages were placed on the terrace above the flood plain so as to avoid wind turbulence produced by dense vegetation near the river. This also provides for easy access to the gages during heavy rains or when the flood plain is inundated.

Data from the wedge-type gages are punched on cards in the field, and the cards are used directly as digital-computer input. Total precipitation and its time of occurrence, as observed at recording gages, are used to extrapolate the rainfall catch of the nonrecording gages over shorter periods of time. The Thiessen polygon method is employed to obtain an estimate of the mean depth of rain on each subreach during a waterbudget period.

Measurements indicate that the south side of the river receives more precipitation than the north side.

\footnotetext{
1 "Convective-type storms, [in the Southwest] therefiore, do not ordinarly produce rain of a general nature nor is there influence of particular note when consideration of peak discharges from larger watersheds is concerned. They are of utmost importance, however, in the production of maximum runoff from watersheds of ten square miles or less or from portions of large watersheds." (Dorroh, 1946).
}

Although long-term records are not available, the orographic effect produced by the high mountains south of the river seems to be reflected in the catches of the nonrecording gages at the end of each section.

\section{SURFACE WATER}

By D. E. BurkhaM

\section{PURPOSE AND SCOPE}

Surface-water aspects of the project consist of measurement of streamflow for water-budget studies and evaluation of changes in low-flow and floodflow channels of the Gila River. Measurement of streamflow is important because: (1) during many periods streamflow is the largest item in the water budget, (2) streamflow is the major source of ground-water recharge, and because of hydraulic interconnections, streamflow influences the movement of ground water, and (3) streamflow data are more accurate than some other data and can be used to test evaluations of other factors.

Evaluation of changes in the low-flow and floodplain channels, as affected by vegetation alteration, is not a main objective of the study, but attempts will be made to document these changes. Natural river channels or streamflow conveyance systems are formed, altered, and maintained through the interrelation of the forces involved in the flow of water, movement of debris, and stresses in the mobile boundary of the channel (Leopold. 
and others, 1964, p. 169). Gravity provides the force by which water and debris are moved, and resistance to flow is provided by the boundary. The forces and stresses involved are related to the character and composition of the debris carried by the water and to the materials in the boundary. Vegetation on the boundary adds to the resistance to flow and to the stability of the boundary. Changes in erosion, deposition, and resistance to flow, therefore, may be expected when the vegetation is altered. Removal of saltcedar and substitution of grasses may cause the river channel to change frequently in size, shape, and location. In addition, changes may occur in the channel pattern and sinuosity. It is possible, of course, for changes in stream channels to take place simultaneously with changes in the regimen of flow and with the removal of vegetation, so that changes attributable to vegetation modification would be difficult to detect.

\section{PHYSICAL DESGRIPTION OF THE GILA RIVER DRAINAGE AREA}

The Gila River drainage area is divided, for discussion, into (1) the Gila River above the study reach, (2) tributaries adjacent to the study reach, and (3) the Gila River through the study reach.

\section{GILA RIVER DRAINAGE AREA ABOVE THE STUDY REACH}

The drainage area of the Gila River above the study reach is about $29,800 \mathrm{sq} \mathrm{km}$ (square kilometers) $(11,500$ $\mathrm{sq} \mathrm{mi}$ ) and extends eastward into the mountains of New Mexico. The altitude of the basin ranges from 760 to $3,350 \mathrm{~m}(2,500$ to $11,000 \mathrm{ft})$ above mean sea level. Topographically, the basin is typical of those in the Basin and Range physiographic province (Fenneman, 1931 ) and is a comparatively flat, wide, sediment-filled valley between narrow rugged mountain ranges.

Native grasses and shrubs in the valleys and lower levels of the basin are generally sparse, but much of the mountain area is forested. The valley's flood plain has a dense cover of phreatophytes, consisting primarily of saltcedar (Tamarix pentandra) and mesquite (Prosopis). Much of the basin is used for grazing. Currently (March 1965), there are many small detention and retention reservoirs associated with range conservation and grazing on the Gila watershed.

About 27,900 hectares $(69,000$ acres $)$ of valley land above the study reach is under cultivation (U.S. Geological Survey, 1961, p. 416), and the usual crops are cotton and alfalfa. Irrigation water is obtained from the Gila River at several diversion points and from groundwater storage. At the present time (March 1965), there are no large manmade reservoirs in the Gila River basin above Calva, Ariz.

\section{TRIBUTARIES ADJACENT TO THE STUDY REACH}

The area tributary to the study reach, $717 \mathrm{sq} \mathrm{km}(277$ sq $\mathrm{mi}$ ), is drained by many ephemeral washes. The tributary basins are long and narrow, ranging in size from less than 0.3 to $101 \mathrm{sq} \mathrm{km}(0.1$ to $39 \mathrm{sq} \mathrm{mi})$, and drain the Gila Mountains on the north and Mount Turnbull on the south. The altitude of the basins ranges from 760 to $2,700 \mathrm{~m}(2,500$ to $9,000 \mathrm{ft})$. Extremely steep slopes and sparse vegetation induce rapid runoff.

\section{GILA RIVER THROUGH THE STUDY REACH}

The flood plain through subreaches 1 and 2-numbered in downstream order-is about 900 to $1,200 \mathrm{~m}$ ( 3,000 to $4,000 \mathrm{ft}$ ) wide. During low and medium flows the main channel is 24 to $30 \mathrm{~m}$ ( 80 to $100 \mathrm{ft}$ ) wide, has a slope of about 0.001 meter per meter $(0.003 \mathrm{ft}$ per foot), and consists primarily of pools and riffles. The bottom of the pools usually consists of easily erodible sand during low flows, while the riffles are formed from fairly stable gravel bars. The banks of the main channel and the flood plain are stabilized by saltcedar and mesquite.

The main channel and flood plain of subreach 3 are different from those of subreaches 1 and 2-presumably because of the influence of San Carlos Reservoir. Sediment deposited in the reservoir during the period of maximum storage, 1941-42, and subsequent sediment deposition from flows in the San Carlos and Gila Rivers have appreciably decreased the slope of the main channel and flood plain. The vigorous growth of saltcedar has gradually encroached on the channel and, together with the reduced slopes, has decreased the flow capacity of the channels. Overbank flow of sedimentladen floodwater has resulted in the formation of natural levees by deposition when the velocity of the water is reduced on entering the saltcedar thicket. The deposition of sediment has aggraded the channel and its levees until they are the highest part of the flood plain (fig. 5). Floatable debris-mainly logs-carried by the floodflows has been deposited in the channel owing to the screening effect of the saltcedar, and the end result is a plugged channel; additional sediment was then deposited in the log jam (fig. 6).

The development of natural levees and the decrease in channel slope have been gradual; however, the process of channel plugging and filling progressed upstream at a rapid pace once $\log$ jamming started. Aerial photographs taken in 1935, 1947, and 1962 indicate no $\log$ jamming and no significant change in channel location from 1935 to 1962 . A log jam on the Gila River 2.4 kilometers (11/2 miles) above the mouth of the San Carlos River was first observed in January 1963. This 


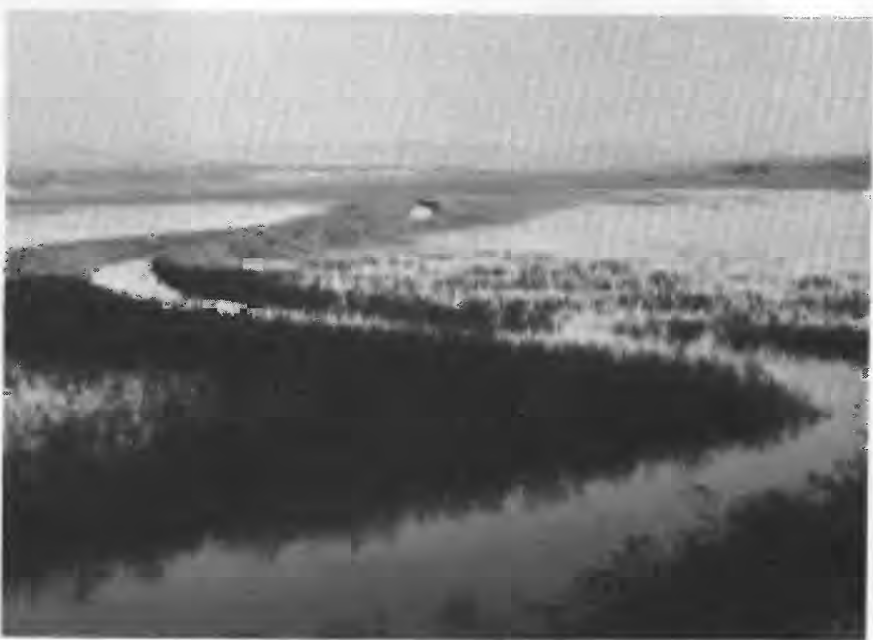

Figure 5.-Lower part of the project area during high water and the natural levees formed as a result of the saltcedar reducing the velocity of the water.

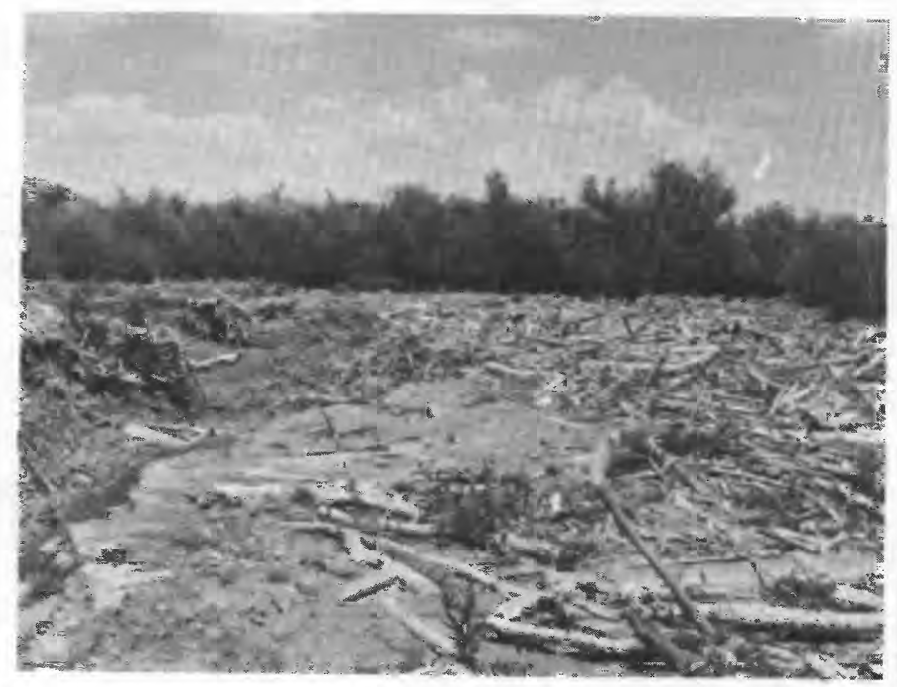

Frgure 6.- Log jam and sediment accumulation below section 23.

jam probably occurred during the floodflows of September 27 to 30,1962 . Since January 1963, the upstream progress of the channel plugging has been observed and has been documented by photographs. During the summer flows of 1963 and 1964, the jam progressed upstream 4.8 and 8.8 kilometers ( 3 and 5.5 miles) from the mouth of the San Carlos River, respectively. At the present time (March 1965), the upstream end of the log jam is within $90 \mathrm{~m}(300 \mathrm{ft})$ of section 23.

Channel plugging by log jams has increased the area and duration of ponding behind the natural levees; reservoir inflow may have been decreased as a result of higher evapotranspiration rates from these ponds and swampy areas.

\section{STREAMFLOW GHARACTERISTICS}

\section{GILA RIVER}

Flow in the Gila River, which constitutes a large part of the water in the water-budget study, comes from two seasonal types of precipitation. Flow from summer precipitation extends from July through October, and flow from winter precipitation extends from November through June.

Summer streamflow results mainly from small thunderstorms, but occasional frontal activity brings precipitation that produces widespread runoff in late September and throughout most of October. Streamflow caused by summer precipitation generally varies considerably within a short period of time. Periods of no flow occur during most summers. Sediment concentration is generally high during summer flow. Average summer flow from 1930 through 1961 was $5.15 \mathrm{cu} \mathrm{m}$ per sec (cubic meters per second) [182 cfs (cubic feet per second)], ranged from 0 to $790 \mathrm{cu} \mathrm{m}$ per sec $(27,900 \mathrm{cfs})$, and was 26 percent of the average annual amount.

Flow from November through June is mainly from frontal storms, snowmelt, or ground-water storage and may be fairly constant for long periods. Flow, if any, is generally small in May and June.

The average November through June flow from 1930 through 1961 was $7.16 \mathrm{cu} \mathrm{m}$ per sec (253 cfs), ranged from 0 to $609 \mathrm{cu} \mathrm{m}$ per sec $(21,500 \mathrm{cfs})$, and was 74 percent of the average annual amount.

Major flows of record have occurred during the winter as a result of large amounts of widespread rainfall, a warming trend during a time of large snow accumulation, or extensive rainfall on snow. Maximum known discharge of the Gila River in the study reach was more than $2,800 \mathrm{cu} m$ per sec $(100,000 \mathrm{cfs})$ in 1916 . From 1916 to the present (March 1965), the largest flood was 790 cu $\mathrm{m}$ per sec $(27,900 \mathrm{cfs})$ in 1941.

\section{TRIBUTARIES}

Flow in tributaries to the study reach generally occurs in summer as a result of thunderstorms and is characterized by high peak rates and small volumes. Only a small amount of tributary flow reaches the Gila River as surface runoff. Some infiltrates to the tributary alluvium, the Gila River terrace alluvium, and to the Gila River flood plain. Some is ponded behind natural levees of the Gila River and is depleted by infiltration and evaporation. Because of infrequent occurrence and small volume, runoff from tributaries is an important factor in only a small number of budget periods. If a water-budget study is to be useful during the rare occasions when tributary surface flow is large relative to water from other sources, flow records must be accurate. 


\section{DATA-COLLECTION PROGRAM}

Data necessary to evaluate factors in the water-budget study include: (1) continuous records of surface flow to and from each subreach, (2) discharge measurements at about 6 -week intervals at each cross section to evaluate the interchange of surface- and ground-water flows, and (3) stage readings, usually at about 3-week intervals, at each cross section.

\section{GILA RIVER SURFACE FLOW}

Gaging stations on the Gila River in the study area are maintained at the end points of each subreach and are referred to as: (1) near Bylas, (2) at Calva, (3) near Calva, and (4) above Coolidge Dam. Each gaging station is equipped with a 15-minute digital stage recorder and a continuous analog stage recorder, both of which are activated by the same float. The continuous record of stage is desired in addition to the punched record during measurements of needle-peak-type flows. The continuous graph also is useful in defining shifts in the stage-discharge relation.

A brief description of each gaging station follows.

GILA RIVER NEAR BYLAS, ARIZ.

The gage is on the downstream side of the bridge on U.S. Highway 70 (fig. 1). Flow past the stilling well is somewhat turbulent, but its effect on the stage-discharge relation is not excessive.

High-water measurements were made from the bridge through the spring of 1964 . However, because of large approach angles, turbulence, excessive scour around the piers, and uneven velocity distribution, the bridge site was not ideal for measurements of high flow. A cableway that spans the main channel was installed $43 \mathrm{~m}$ (140 $\mathrm{ft}$ ) downstream in the summer of 1964. Flows in excess of the capacity of the main channel, about $110 \mathrm{cu} \mathrm{m}$ per sec $(4,000 \mathrm{cfs})$, still must be measured from the bridge. Low flows are measured at wadable sections near the gage.

The control section for flows ranging from 1.4 to 110 cu $\mathrm{m}$ per sec (50 to $4,000 \mathrm{cfs}$ ) is an old road crossing $46 \mathrm{~m}$ (150 ft) downstream from the gaging station. The section of gravel, small rocks, and sandbanks overgrown by saltcedar is fairly stable. The low-water control is the shifting sand bars that form upstream from the old road crossing.

\section{GILA RIVER AT CALVA, ARIZ.}

A gaging station has been in operation at this site since October 1929. The station was originally equipped with a continuous analog stage recorder, and the stilling well was attached to the downstream side of the railroad bridge that spans the Gila River flood plain. Many fac- tors-including trash accumulation, shifting of the lowflow channel, and channel changes associated with bridge maintenance-made the location undesirable. A new station was established in December 1962, $162 \mathrm{~m}$ (530 ft) below the bridge. The new station, originally a bubble-gage type but currently a stilling-well type, is on the left bank of the river.

Before 1962, all high-water measurements were made from the railroad bridge. Because of large approach angles, turbulence, excessive scour around piers, and uneven velocity distribution, the bridge site was not ideal for high-water measurements. In December 1962 a cableway spanning the main channel was constructed $122 \mathrm{~m}(400 \mathrm{ft})$ downstream from the bridge. Flows in excess of the capacity of the main channel, about 110 cu m per sec $(4,000 \mathrm{cfs})$, still must be measured from the bridge. Measurements of low flow are made at wadable sections at several places near the gage.

The channel control of sand and gravel is unstable. There is a fairly stable gravel bar in the channel $60 \mathrm{~m}$ $(200 \mathrm{ft})$ below the present gaging station that may act as a partial control during flows near bankfull stage. Vegetation along the banks also affects the stage-discharge relation at flows near bankfull stage or higher.

GILA RIVER NEAR GALVA, ARIZ.

This station was started in January 1963 when a bubble gage was installed on the right bank of the river $37 \mathrm{~m}(120 \mathrm{ft})$ upstream from an old highway bridge near the mouth of Salt Creek (fig. 1). The wood shelter burned in June 1963, and all the instruments and about 3 weeks of stage record were destroyed. Another bubble gage was installed in August 1963. The bubble gage was abandoned in October 1963, and a stilling-well-type gage was installed. The stilling well of the new gage is attached to a concrete pier of the bridge on the right bank of the main channel $37 \mathrm{~m}(120 \mathrm{ft})$ downstream from the bubble-gage site.

A measuring cableway that spans the main channel was installed about halfway between the site of the bubble gage and the stilling-well-type gage. No attempt will be made to measure flows in excess of the capacity of the main channel, about $85 \mathrm{cu}$ m per sec $(3,000 \mathrm{cfs})$. Because of the wide flood plain and poor measuring conditions low-flow measurements are made at various wadable sections in the channel near the gage.

GILA RIVER ABOVE GOOLIDGE DAM, ARIZ.

Accurate measurement of streamflow at the downstream end of subreach 3 has been extremely difficult because of channel plugging by debris. In 1962 a bubble gage was installed on the right bank of the main channel about 4 kilometers (21/2 miles) upstream from the mouth of the San Carlos River. At that time 
the main channel was $30 \mathrm{~m} \mathrm{(100} \mathrm{ft)} \mathrm{wide} \mathrm{and} \mathrm{had} \mathrm{a}$ bankfull capacity of about $57 \mathrm{cu}$ mer sec $(2,000 \mathrm{cfs})$. Only 4 months of streamflow record was obtainedand this was largely faulty because of malfunctions associated with the bubble gage-before the channel became filled with debris and the flood plain became a lake.

In February 1964 a new gaging station was established about 3 kilometers ( 2 miles) upstream with a stilling-well-type gage. The sand-bed channel at this site has a conveyance capacity of about $43 \mathrm{cu} \mathrm{m}$ per sec $(1,500 \mathrm{cfs})$ at bankfull stage. A cableway spanning the main channel was constructed in May 1964.

Because of channel plugging, only small flows currently can move down the main channel-the remaining streamflow spills onto the flood plain. As a result, only records of median and low flow are being obtained.

When the project was started in 1962, bubble gagesmanometers using gas to transmit river stage by pressure-were installed at the "at Calva," "near Calva," and "above Coolidge Dam" sites, but they were soon discontinued owing to instrument malfunctions and incorrect registering of gage heights. The poor record generally occurred during stage recessions and apparently resulted from plugged orifices caused by the movement and deposition of sand and clay over them.

Discharge measurements, which are necessary to establish the stage-discharge relation at each gaging site, are made using established techniques. Because the channels are composed of sand and gravel, they are subject to some shifting at all flows, although shifting is not excessive. Some factors contributing to changes in the stage-discharge relation are scouring and filling in the controlling reach of the river, sediment in transport, and seasonal vegetation changes. Most shifting in ratings are probably associated with the movement of sediment.

To insure necessary accuracy of flow records, frequency of discharge measurements is geared to the movement of sediment. Sediment transport is high in the summer during the continual variation of flow rates and therefore requires that discharge measurements be made about three times weekly. Measurements during the more constant winter flows are made about once a week.

\section{TRIBUTARY SURFACE FLOW}

The tributary surface flow generally contributes water to the reach for only a small part of the time and is assumed to be a small part of the total waterbudget for most periods. Therefore, accurate records of flow for each tributary will not be required. Diff- culties in accurately measuring high rates of discharge from tributaries will require that water budgets which include large storms from tributaries be omitted from the study.

In order to estimate surface flow from tributaries, 62 gaging stations -16 with continuous stage recorders and 46 with crest-stage gages-were installed. The tributaries on which the 16 recording gaging stations have been established were selected on the basis of basin size, physiographic characteristics, and orientation along the study reach.

Because runoff increases with the size of a basin, 10 of the 16 recording gages were established in the 10 largest basins. About 54 percent of the total tributary area is included in these basins. The remaining six recording gage sites were selected on the basis of physiographic characteristics and orientation. About $396 \mathrm{sq} \mathrm{km} \mathrm{(163}$ sq $\mathrm{mi}$ ) or 59 percent of the total tributary area is included in these 16 basins.

The 16 recording gaging stations were established at highway or railroad structures (fig. 1). The control sections at the gaging stations range from stable concretebox culverts to unstable sand. Owing to the extremely steep channel slopes, the velocity of the flow past the gaging sites is almost always supercritical.

The 46 crest-stage gages (fig. 1) are maintained on tributaries having drainage basins ranging in size from 0.2 to $21 \mathrm{sq} \mathrm{km}$ ( 0.1 to $8 \mathrm{sq} \mathrm{mi})$. These gages are located at bridges or culverts wherever possible. The control sections are similar to those at the recording gages.

Discharge records are obtained for tributaries equipped with the continuous recorders by using established techniques. Current-meter measurements are made whenever possible; otherwise, data necessary for indirect measurements are obtained.

Discharge estimates at crest-stage gages are obtained by the use of a peak-discharge versus storm-volume relation. This relation is established using data from calibrated stations equipped with the continuous recorders. The peak discharge is obtained from ratings defined by established techniques.

\section{CHANGES IN THE STREAMFLOW GONVEYANCE SYSTEM}

Changes in the streamflow conveyance system as a result of vegetation alteration may be slow or rapid. Evaluations of changes will be made by comparing the conveyance systems of treated (cleared) and untreated (hereafter called the control reach) replicated reaches subjected to the same flows. Analysis of pretreatment history of surface flow, channel configuration, and floodplain vegetation for replicated reaches will be made. 
The analysis will be duplicated after treatment to evaluate changes that can be credited to vegetation alteration. The treated reach is the same as that used in the water-budget study; the control reach, which has not been selected, will be upstream.

The data-collection program in the treated reach consists of (1) repetitive surveys of 15 cross sections of the stream channel and flood plain, (2) repetitive aerial photographs of the stream channel and flood plain, (3) contour mapping of the flood plain and channel, and (4) mapping flood-plain inundation after overbank flows. Changes in resistance to flow associated with vegetation alteration should be reflected in the stagedischarge relation of overbank flow. Data associated with flood-plain inundation will be correlated with the stage-discharge relation in evaluating changes in resistance to flow.

The cross sections were surveyed and permanent horizontal and vertical controls were established in 1964. The vertical control was referenced to mean sea level datum by second-order leveling and the horizontal control was tied to the Arizona Zone East Grid System by third-order triangulation. Monuments were placed at the end of each section and $15.2 \mathrm{~m}(50 \mathrm{ft})$ landward from the bank of the main channel. The sections will be resurveyed at regular intervals.

The present density of phreatophytes precludes precise mapping by photogrammetric methods. After the phreatophytes have been removed, maps at a scale of $1: 7,200$ and contour intervals of $2 \mathrm{ft}(0.6 \mathrm{~m})$ will be prepared from aerial photographs.

Three topographic maps are available. One, which has 5 -ft $(1.5-\mathrm{m})$ contours and a scale of $1: 12,000$, was prepared in 1914-15 by the Soil Conservation Service from planetable surveys. Another, which has 5-ft (1.5-m) contours and a scale of $1: 7,200$, was prepared by the Corps of Engineers from aerial photographs taken in 1946. The map by the Corps of Engineers covers the project reach except for 1 mile (1.6 kilometers) at the upstream end. In 1960 the Geological Survey prepared $71 / 2$-minute quadrangle maps of the area with $40-\mathrm{ft}(12.2-\mathrm{m})$ contour intervals at a scale of $1: 24,000$.

Aerial photographs taken in 1935, 1942, 1947, 1954, and 1964 are available. Additional aerial photographs will be taken as the project progresses.

After the control reach is selected, permanent cross sections will be established, and frequent surveys will be made to document changes in altitude and channel shape and size. Aerial photographs will be used to document changes in channel configuration.

\section{GROUND WATER}

\author{
By R. M. MXrick
}

\section{INTRODUCTION}

The only significant aquifers are the two previously described geologic units-the basin fill and the terrace and flood-plain alluvium. Basin fill underlies the alluvium and forms adjacent valley slopes. Available data indicate that water in the basin fill is under artesian pressure and in places it contributes water to the alluvium. The alluvium rests on the basin fill and underlies the channel, flood plain, and terraces of the Gila River and constitutes the major aquifer in the area. The permeability of the alluvium is high but variable. Water storage changes seasonally in the alluvium.

Movement of ground water is influenced by consumptive use by phreatophytes. During the growing season a tract of this vegetation creates an area of lowered water table similar to that of a field of closely spaced lightly pumped wells. The movement of ground water is further complicated by gravitational movement of water through the alluvium and recharge from the flow of the Gila River, which, in the project area, loses water to the alluvium during most of the year.

Storage coefficients and transmissivity of the alluvium were estimated by means of an aquifer test. The slope of the water table downstream and at right angles to the valley is computed from water levels measured in wells. This information will be used to calculate values of subsurface inflow and outflow both downstream and across the valley, when the thickness of the aquifer at the ends and sides of the three subreaches is known. An estimate of consumptive use at each well can be computed by the phreatophyte-well method (White, 1932). To improve the estimate of storage coefficient at an individual well, changes in storage as measured at soilmoisture observation wells adjacent to each water well will be used.

The depth to water is measured monthly at several stock wells in and near the project area. These wells extend into the basin fill and are perforated below the contact with the alluvium. Measurement of changes in artesian head in these wells will give an indication of changes in rate of inflow from the basin fill.

Flow from the basin fill to the alluvium has been estimated by two different methods as 0.3 to 0.7 meter per square meter ( 1 to $2 \mathrm{ft}$ per square foot) of area of contact per year. Rates of inflow are expected to differ appreciably during the year; therefore, installation of additional wells is planned to measure artesian head throughout the year. 


\section{OBSERVATION-WELL NETWORK}

A network of observation wells was established to measure inflow into and outflow from the project area and to define movement of the ground water. Lines of wells were drilled at about 1.6 kilometer (1 mile) intervals (fig. 1) across the valley. Each line other than section 1 at the upstream end of the project crosses the main channel at about a right angle; section 1 is parallel to the highway embankment. Each section consists of three wells on each side of the river. (See detail of typical cross section, fig. 1). Two wells are near the river channel. Location of the other four wells in each section was determined by considering vegetation type and density and topography.

Drilling of wells in the upper subreach was started in the fall of 1962 and was completed in July 1963. Wells in the middle subreach were completed in December 1963, and those in the lower subreach were completed in June 1964. In the summer of 1964, the water table declined far below any previously measured water level, and it was necessary to deepen some of the wells.

All wells were cased with $11.4-\mathrm{cm}(41 / 2$-in.) lightweight steel tubing into which a $10.8-\mathrm{cm}(41 / 4$-in.) plastic liner was inserted. The wells were not perforated but were left open at the bottom. Where necessary, pipes were encased in concrete at the ground surface to eliminate pipe movement and to prevent surface runoff from raising water levels.

Digital recorders, which punch the water level in code on paper tape at 30-minute intervals, were installed on all observation wells on the cross sections (fig. 7). The size of the wells limited the diameter of the recorder's float to $8.9 \mathrm{~cm}(31 / 2 \mathrm{in}$.) A $5.1-\mathrm{cm}(2-\mathrm{in}$.) steel pipe

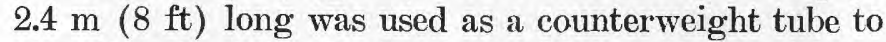
permit water-table fluctuations of $2.4 \mathrm{~m}(8 \mathrm{ft}$ ) without adjusting the float cable. The counterweight tube was plugged in areas where the water table would possibly rise above the bottom of the tube. The possibility of flooding required installation of a submergence cover to protect the recorders.

\section{WATER-LEVEL REGORDS}

The water-level recorders are inspected at least once every 3 weeks, and the charts are removed every 12 weeks (one cross section each week). If a time error on the chart or a minor recorder malfunction has occurred the chart is moved ahead at the time of inspection. Additional recorders are available to replace equipment that requires major repair or adjustments.

When recorder tapes are received from the field, they are edited and forwarded to the Automatic Data Processing Unit, Washington, D.C., for translation to a computer format and storage on magnetic tape. A

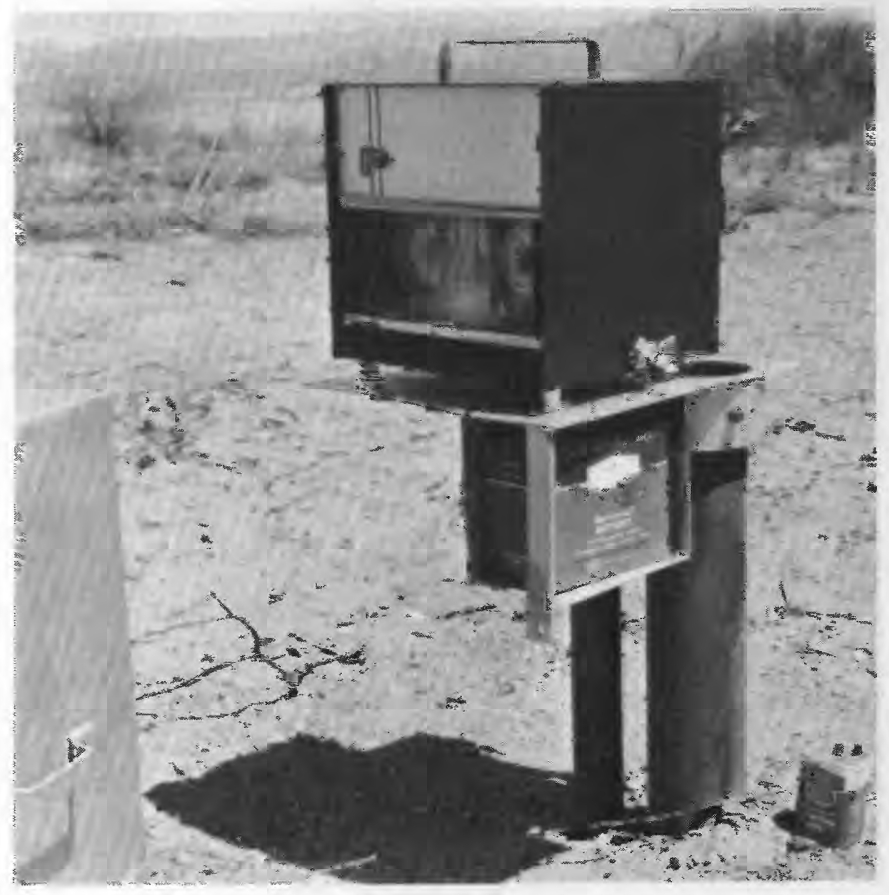

Figure 7.-Water-level observation well, showing installation of digital recorder.

printout of hourly stage and daily maximum, minimum, and mean stage is made. Changes in the water table seldom are more than $0.9 \mathrm{~cm}(0.03 \mathrm{ft})$ during half an hour; therefore, all days having a change in stage greater than $0.9 \mathrm{~cm}(0.03 \mathrm{ft})$ in half an hour are flagged. These flagged readings may indicate a poor record or a marked change in ground-water levels near the river due to a rapid change in river stage.

Data printout sheets are reviewed for poor record resulting from malfunction of the recorder or a sticking float. At the end of each water year the magnetic tape is updated. Where feasible, missing and poor records are estimated on the basis of records from surrounding wells. In the future, updating can be quarterly, if required.

\section{SOIL-MOISTURE OBSERVATIONS}

By' R. M. MYrICK

Changes in moisture storage in the unsaturated zone are important in evaluating evapotranspiration. A network of soil-moisture observation wells similar to that of water-level observation wells previously described was established to measure moisture in storage at the beginning and end of each budget period. Normally, the change in ground-water storage is determined from the specific yield and the change in water-table altitudes. But specific yield, by definition, applies to gravity drainage; therefore, total reduction in storage resulting from withdrawal by phreatophytes cannot be deter- 
mined from observations of changes in the water-table altitude.

To obtain accurate measurements of storage, the soil surrounding the observation wells should be disturbed as little as possible; therefore, the wells were drilled with a hydraulic rotary vacuum drill (fig. 8 ) having a bit slightly smaller than the inside diameter of the casing. The well $\mathrm{S}$ were drilled by extending the drill bit $1.27 \mathrm{~cm} \mathrm{(1/2} \mathrm{in.)} \mathrm{below} \mathrm{the} \mathrm{casing} \mathrm{and} \mathrm{lowering} \mathrm{the}$ casing by hydraulic pressure as the hole was deepened. As drilling progressed, $1.83-\mathrm{m}$ (6-ft) lengths of casing, $4.45 \mathrm{~cm}$ (1.75 in.) in diameter, were brazed together until the casing extended $0.61 \mathrm{~m}(2 \mathrm{ft})$ or more below the lowest expected water table. The casing consists of aluminum pipe having walls $0.32 \mathrm{~cm}(1 / 8 \mathrm{in}$.) thick so as to prevent deformation; aluminum casing was used to minimize its deterioration from highly saline soils and water. After installation, the bottoms were sealed with rubber stoppers (U.S. Department of Agriculture, 1962, p. 116-117), and the casings were bailed dry.

Neutron-scattering soil-moisture meters are used to measure moisture content. Each meter consists of a probe that contains a source of fast neutrons and a slow-

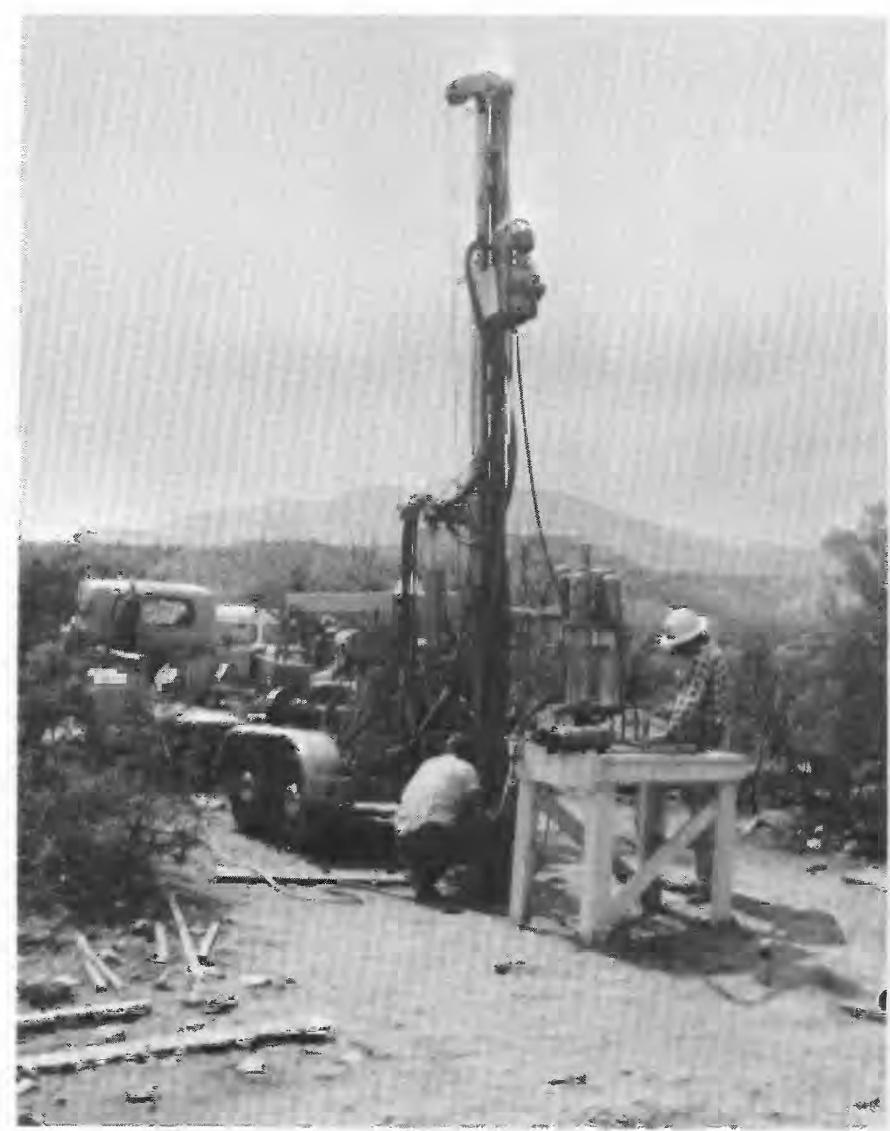

FIGURE 8.-Hydraulic rotary vacuum drill used to install soilmoisure wells. neutron counter attached by a cable to a scaler that records the counts. This method of measuring soil moisture is based on the facts that hydrogen atoms slow fast neutrons more than other elements common in soil and that most hydrogen in soil occurs as moisture. The more moisture present (the greater the number of hydrogen atoms), the greater the number of fast neutrons that are reduced to slow neutrons and the higher the count.

Accurate positioning of the probe in an observation well is important. Near the water table, large changes in moisture are recorded within small changes in depth. A standard reference for positioning the meter, which also serves as a receptacle for the shield of the soilmoisture probe, was made by attaching a steel pipe, $0.30 \mathrm{~m}$ ( $1 \mathrm{ft}$ ) long and $5.08 \mathrm{~cm}$ ( $2 \mathrm{in}$.) in diameter, to the top of the casing; the bottom of this pipe was placed level with the land surface (fig. 9). A steel tape is attached to the probe and cable so that the probe may be positioned at precisely the same depths each time measurements are taken.

Readings (counts) of 1-minute duration are recorded at the $0.15-\mathrm{m}(1 / 2-\mathrm{ft})$ depth and at $0.30-\mathrm{m}(1-\mathrm{ft})$ inter-

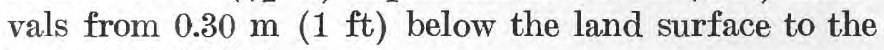
bottom of the hole.

A field calibration was made to check the factory calibration of the meter-count versus percentage moisture-for each probe. Three 0.76-cu m (1-cu yd) tanks were filled several times with different soils having mois-

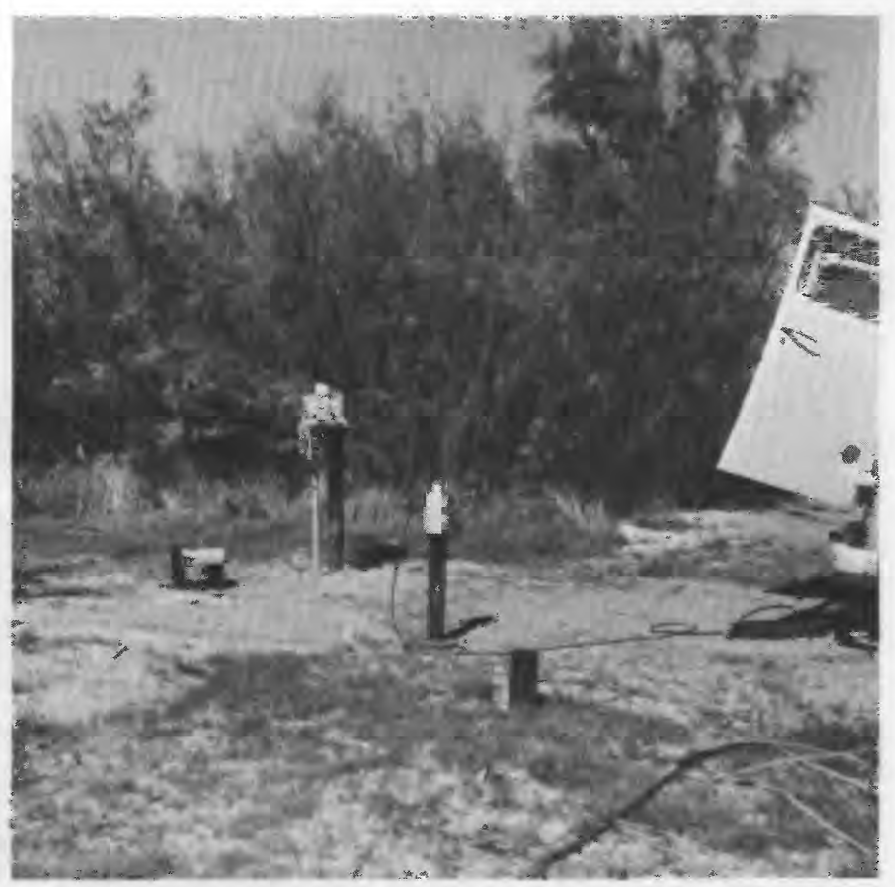

Frauke 9.-Typical observation site, showing observation well with digital recorder and soil-moisture well with neutronmoisture meter in place. 
ture contents ranging from air dry to 20 percent. The probes also were calibrated when the soils were saturated. A calibration curve was then developed for each probe from the tank data.

Two probes were then calibrated against the probe containing the strongest source to reduce small errors introduced when interchanging measuring equipment at an observation well. This calibration was done by making observations at 15 different depths in each of 10 wells with each of the three probes. The 10 well sites were selected with an equal distribution of data over the entire range of moisture in storage and to represent several types of soil. Rating curves for the two probes with weaker sources were developed using the percentage moisture as measured by the probe with the strongest source. The difference between the curves developed by this method and the best-fit curves constructed from the first calibration, although small, would introduce an error in the soil-moisture data when equipment was interchanged.

Soil-moisture measurements are made in one subreach each week. Soil-moisture data and other pertinent information are punched on 40-column cards in the field. A computer program converts the field data to percentage moisture by volume, using the calibration developed for each of the probes. A printout is obtained of the percentage moisture, change in inoisture content since the last observation, and other pertinent data that have been entered on the cards. The percentage moisture for each depth is punched automatically on a second set of cards to be used in the analysis of soil-moisture data.

The zone of aeration, in which pores are normally occupied partly by water and partly by air, extends from the water table, or the top of the zone of saturation, to the land surface. The zone of aeration from the land surface downward may be divided into the belt of soil water, the intermediate belt, and the capillary fringe (Meinzer, 1942, p. 393-394). Normally the belt of soil water is not saturated, but it is recharged by precipitation and, in places, occasionally by floodwater. The intermediate belt extends from the lower limit of the belt of soil water to the upper limit of the capillary fringe, and it is recharged by downward-moving water. The capillary fringe extends upward from the water table to the maximum height of capillary rise or to the belt of soil water if the water table is only a few feet below land surface.

Data from each soil-moisture observation well are separated according to each of the three belts of the zone of aeration, and changes in storage during a budget period are calculated for each belt. Changes in storage related to precipitation, and occasionally to flooding, are restricted mainly to the belt of soil water. Changes in storage in the intermediate belt, penetrated only by the deeper wells on the terraces, are only minor over long periods of time. Major changes in storage are restricted to the capillary fringe and are controlled by vegets. 1 cover, depth to water, and fluctuations of the water table.

Change in storage during a budget period in each belt in each subreach are computed by the Thiessen polygon method. The bottom of the soil-water belt was set arbitrarily at $1.37 \mathrm{~m}(4.5 \mathrm{ft})$ below land surface because little or no change in storage has been observed between this depth and the capillary fringe in the wells on th? terraces. The intermediate belt extends from this depth to the maximum recorded capillary rise. The capillary fringe extends from the water table to the intermediate belt or to the soil-water belt in wells on the flood plain where the intermediate belt is not present. Further: analyses will require a more exact method of determiring the extent of these belts in individual wells.

\section{VEGETATION}

By R. M. TURNER

\section{CHARACTERISTICS}

Phreatophytes grow along streams and on floo' plains and stream terraces where favorable moisturs balance enables these plants to attain a height and density far greater than that of adjacent upland communities. The most common phreatophytes include mesquite (Prosopis juliflora var. velutine (Woot.) Sarg.), willow (Salix sp.), cottonwood (Populus fremontii Wats.), seepwillow (Baccharis glutinosa Pers.), saltcedar ( $T a$ marix pentandra Pall.), and seepweed (Suaeda torreyana S. Wats.). Campbell and Dick-Peddie (1964) described phreatophytes along the Rio Grande in New Mexico, where many of these same plants grow.

The vegetation of the uplands (basin fill and older terraces), in contrast to that of the valley bottom, forms uniform low open stands. The most abundant plants here are creosote bush (Larrea tridentata (Sesse \& Mo? ex DC.) Coville), white thorn (Acacia constricta Benth.), catclaw (Acacia greggii A. Gray), and mesquite.

There is a strong mosaic pattern to the vegetation of the terraces and, particularly, the basin fill in the part of the Gila River valley included in this study. Soils of strikingly different chemical and physical characteristics are exposed. The plant life has responded to tro variety of habitats and has assumed a patchwork design, often with sharp boundaries between adjacent patches.

Several distinct phreatophyte communities occupy some of the lowlands. About 1,420 hectares (3,500 acres) are dominated by mesquite, 1,900 hectares (4,700 acres) by saltcedar, and 63 hectares (155 acres) by seepweed; about 24 hectares ( 59 acres) are barren. 
The mesquite community is above the flood plain on fairly stable land surfaces. Mesquite forests often extend to the top of recent vertical cuts where an abrupt transition occurs to the flood-plain vegetation below. The outer edge of the mesquite-dominated areas usually abuts the base of bluffs bordering the Gila River valley. Mesquite also grows up tributary washes. Along the floors of these washes, the phreatic zone gradually merges with upland xerophytic communities, and mesquite plants decrease in size along the gradient of diminishing water availability.

Other woody perennials growing with mesquite are catclaw, white thorn, grey thorn (Condaliopsis lycioides (A. Gray) Suesseng.), and four-wing saltbush (Atriplex canescens (Pursh) Nutt.). The total coverage of these plants seldom exceeds that of the mesquite with which they grow.

The trees of the low mesquite forest may be $41 / 2$ to 6 $\mathrm{m}$ (15 to $20 \mathrm{ft})$ high. The trees lose their leaves in late fall and produce new ones in April or May. At the onset of the summer rainy season, the trees produce a second crop of leaves, which increases the total transpiring surface. The second flush of leaf growth is apparently in response to precipitation and the renewed supply of available moisture in the upper soil horizons.

Saltcedar covers more than 50 percent of the area and generally grows in areas of overbank flooding, although it occupies some arid uplands that have previously been subjected to flooding. Where saltcedar is most dense, it is usually unaccompanied by other woody perennial plants, but seepwillow may grow widely scattered among taller saltcedars or as a narrow fringe along the open channel margin.

Saltcedars form nearly impenetrable thickets $4 \frac{1}{2}$ to $6 \mathrm{~m}$ (15 to $20 \mathrm{ft}$ ) high where growth is most dense. In other places the stands are open, probably because of poor synchronization between flooding and seed production, frequent burning, and a deep water table.

The densest and tallest saltcedar grows near the river channel. The transition zone is abrupt between areas occupied by saltcedar and by adjacent vegetation. The sharply defined boundaries probably result from two characteristics of the seeds of this plant. First, because each saltcedar plant produces large quantities of seeds, many are deposited simultaneously. Second, germination and establishment depends on flooding. Level flood plains, uniformly flooded and densely peppered with seeds of saltcedar, later support heavy stands of this aggressive plant; adjacent areas that have not been flooded do not.

Saltcedar stands are thinnest at the lower end of the project area on old terraces that were colonized by the plant after San Carlos Lake reached its highest stage
(1941-42). Preflood vegetation, mainly creosote bush, was killed by submergence, and saltcedar replaced it as the lake water receded. At the present time (1965), the saltcedars are short (about 1 to $2 \mathrm{~m}$ (3 to $6 \mathrm{ft}$ )) and widely spaced, and each is a cluster of small stems, most of which are dead. A few new sprouts are produced annually, but most die later through drouth pruning. Where the water table is deep, these stunted plants probably depend wholly on rainfall for moisture and are, therefore, xerophytes and not phreatophytes. Once established, the plant is capable of growing under a wide range of moisture conditions.

The saltcedar is leafless during the winter; branchlets and scale leaves first appear in March or April. It is in full leaf by June or July and remains in leaf until late fall, when the branchlets, which bear the scale leaves, are shed.

Seepweed grows in dense stands toward the outer edges of the flood plain occupied by saltcec'ar. Until recently, most seepweed was in the upper subreach, but because of cultivation only small areas of this regetation remain.

Seepweed, a herbaceous perennial with narrow fleshy leaves, often grows on saline soil with other halophytes, such as pickleweed (Allenrolfea occidentalis (S. Wats.) Kuntze). Each plant forms a compact globos clump 1 to $11 / 4 \mathrm{~m}$ (3 to $4 \mathrm{ft}$ ) high. They usually form dense stands that change from dark green during tho summer to brown in winter, when all but the main stems die.

\section{PLAN OF STUDY}

The volume of transpiring vegetation has to be known to evaluate effects of phreatophyte removal, but, because the size of the project area is large, only a generalized method of determining the volume can be used. The method used is the volume-density method described by Gatewood and others (1950). Data for expressing volume density are derived from three measurements : total area occupied by vegetation, $\mathrm{f}$ ercentage of the area actually covered by plant crowns, and height of plants.

The area occupied by plants can be determined readily from aerial photographs. For this purpose black and white prints at a scale of about $1: 14,000$ were used. Tentative boundaries of vegetation types (patches with uniform appearance) were first drawn on the photographs. All areas were then checked in the field, and new boundaries were drawn or old ones were removed where the field check revealed errors (Hcrton and others, 1964). Dominant plants of each area were then listed in order of abundance.

With boundaries established, percentage coverage may be determined from the photographs, using a dissecting binocular microscope one ocular of which is 
fitted with a square reticle divided into 100 squares, each 1 square millimeter in area. Each square was considered to be a plot projected onto the photograph. The magnification of the microscope was set on $\times 10$ so that a 1 millimeter square of the reticle circumscribed a $1 \mathrm{~cm}$ square on the aerial photograph, and the image within the square was enlarged 10 times. Each plot thus established is roughly equivalent to 2 hectares (5 acres) on the ground. Total coverage was estimated by sampling one-eighth of the total area.

Coverage of plant crowns in each of the sample plots was estimated according to a procedure described by Daubenmire (1959), using six broad classes of coverage during the plot-by-plot microscopic examination yet ultimately arriving at a numerical value for percentage coverage.

Average plant height is usually estimated during the field reconnaissance. Broad classes of plant height are commonly used where great precision is not warranted. Thus, for saltcedar, the following three classes were

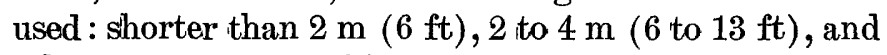
taller than $4 \mathrm{~m}(13 \mathrm{ft})$. The value of $4 \mathrm{~m}(13 \mathrm{ft})$ was accepted from Gatewood and others (1950) as the maximum foliage depth attained by saltcedar crowns in

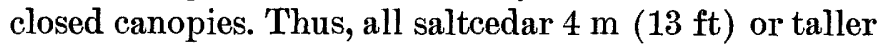
was assigned a vertical density ${ }^{2}$ of 100 percent. Vegetation types falling in the 2- to 4-m (6.5- to $13.0-\mathrm{ft}$ ) class were assigned a vertical density of 75 percent (midway between the upper and lower limits of the class); for plants shorter than $2 \mathrm{~m}(6.5 \mathrm{ft})$ a vertical density of 25 percent was used. Vertical density of mesquite and seepweed is not known and will require special study.

\section{PHREATOPHYTE REMOVAL}

Clearing vegetation rapidly and completely from the reach is a problem of great importance. Parker and Martin (1952) have reviewed methods for mesquite eradication. Robinson (1964) described all recent saltcedar-eradication research in eight Western States. The most promising methods for eliminating saltcedar and mesquite are mechanical clearing and spraying with herbicides. Although it is costly and slow, mechanical clearing probably can be used except where flooding or high water table make the use of heavy equipment infeasible.

Herbicides, such as Silvex (2-, 4-, 5-TP), have proven effective against saltcedar, but plant kill usually is less than 100 percent on flood plains (Robinson, 1964, p. 9). Silvex was applied in mid-May 1964 by helicopter at the rate of 4.5 kilograms per hectare ( 4 pounds per acre) on a 16-hectare (40-acre) plot 1.6 kilometers

\footnotetext{
2 See Gatewood and others $(1950$, p. 25) for definitions of vertical density, aerial density, and volume density.
}

(1 mile) downstream from section 23 . The Silvex killed only about 20 percent of the saltcedar, except in lowlying areas where floodwaters rose a few months after herbicide application and submerged the root crowns: Here the herbicide was nearly 100 percent effective, which encourages its use in lowland areas.

The final selection of a clearing method will depend upon criteria such as cost (including preparation of the soil for revegetation) and speed (rapid clearing is desirable).

\section{REVEGETATION}

Removal of phreatophytes from the banks or flood plain of a river ordinarily is not practical, regardles: of the water used by the plants. Cleared areas will not. remain clear for long because, inevitably, seeds and fruits are carried to such favorable habitats, and nev plants shortly take root. The phreatophytes must b 3 replaced by less objectionable vegetation if removal is to be practical. Replacement vegetation should transpire less than the phreatophytes and should supply a valuable product.

Revegetation is being studied by the Watershed Management Department of the University of Arizona. Two cleared and fenced areas are being used to screen seven grass species for use under irrigation and dryland conditions. The grasses are being judged by the following criteria: rate of seedling emergence after sowing, rate of establishment, forage yields with and without irrigation, and ability to withstand reinfestation $b_{\text {: }}$ phreatophytes. Screening also includes transpiration studies.

\section{QUALITY OF WATER}

By R. L. LANEY

\section{CHARACTERISTICS}

Water quality may be considered in terms of four major hydrologic environments: the Gila River; its tributaries; alluvium along the river; and the basin-fill deposits on which the alluvium lies. Water from each environment has identifiable characteristics.

Dissolved-solids content of Gila River water varie inversely with discharge-less than $500 \mathrm{mg} / \mathrm{l}$ (milligrams per liter) at high flow to more than $4,000 \mathrm{mg} / \mathrm{l}$ at low flow. The chemical composition of the river water also varies with discharges-sodium bicarbonate type at high flow and sodium chloride type at low flow. Flow: usually are highest in July, August, and September. During most of the year, sodium and chloride are the principal ions.

Major tributary flow, which is a result of localized high-intensity rainfall, is a sodium-calcium bicarbonate type and contains less than $400 \mathrm{mg} / \mathrm{l}$ dissolved solids. 
Water from 56 observation wells that tap the alluvium was analyzed. Dissolved-solids content ranges from about 1,000 to $20,000 \mathrm{mg} / \mathrm{l}$. Sodium, chloride, and sulfate are the principal constituents.

Water from 10 wells tapping the basin-fill was analyzed. Dissolved-solids content ranged from 214 to 847 $\mathrm{mg} / \mathrm{l}$ and averaged $411 \mathrm{mg} / \mathrm{l}$. Generally, the water is a calcium-sodium bicarbonate type.

\section{PLAN OF STUDY}

Water-quality investigations began in June 1964. The object was to determine the chemical quality of the water and any changes caused by phreatophyte eradication. The study involves: (1) conductivity monitoring and periodic sampling of water in the Gila River, (2) determination of areal distribution of dissolved solids in the water in the alluvium four times a year, and (3) determination of the chemical composition of soil water.

\section{DATA ANALYSIS}

Maps that show areal distribution of dissolved solids in the water in the alluvium have been prepared based on conductivity of water from more than 70 wells. These maps will be included in a later report. Conductivity measurements are taken in March, June, September, and December. Dissolved solids are obtained by multiplying the conductivity in micromhos by a factor that is appropriate for the water tested. This factor was previously determined by dividing the analytically determined dissolved solids by conductivity of 56 water samples from the alluvium and taking the arithmetic mean. The dissolved solids values are grouped into six zones of dissolved solids and each zone is assigned a number from 1 through 6 . The project area has been divided by a grid into segments of about 23 acres each. A tabulation is then made of the dissolved-solids zone for each segment. These data are processed by a computer and compared to other parameters obtained on the same grid, such as depth to water and foliage density, height, and species. In addition, a tabulation is made of frequency of occurrence of the dissolved-solids zones. These data will be used to show changes in water quality caused by phreatophyte eradication. In an attempt to verify this change, a frequency distribution, arithmetic mean, and median is being determined for the conductivity data for each sampling period.

Interpretation of data collected thus far indicates that the amount, location, frequency, and duration of floodflow are major controls on ground-water quality in the Gila River flood plain, and these controls may obscure any possible effects of changes in amounts of phreatophytes.

Preliminary data regarding chemical composition of soil water in the alluvium indicate considerable vertical and lateral variation in dissolved-solids content. This may have a profound effect on the quality of ground water, if soil water of high dissolved-solids content contributes to ground-water recharge during a period of rising water table. Prolonged flooding by the Gila River apparently flushes the salts from the soil. When the flood waters have receded, dissolved-solids content of the soil water gradually increases. Soil-ws.ter studies may aid in determining the relation between recharge, evapotranspiration, and water quality.

\section{SOIL-MOISTURE-ENERGY FACTORS II 'FLUENC- ING EVAPOTRANSPIRATION IN RIPARIAN VEGETATION}

\section{By R. F. MILlez and I. S. MCQueen}

Soil-moisture-energy relations under and adjacent to selected riparian vegetation in the Gila and San Carlos Rivers, are also being studied. These studies are designed to evaluate probable effects of tree removal on flood-plain soil moisture. The principal question is: Will increased solar energy reaching soil surface after tree removal cause increased evaporation that will offset reduced transpiration?

Changes in energy gradients that may result from increases in solar energy reaching the soil surface after tree removal are inferred from differences measured under and adjacent to selected trees. Soil-moisture stress and soil-temperature gradients are the princi pal parameters measured at each site. These are supplemented by laboratory measurements of chemical and physical properties of soil obtained near measuring rites.

Differences in characteristics of use of scil moisture by saltcedar, cottonwood, willow, mesquite, and adjacent bare ground are being studied. Comparisons of soil-moisture stress and temperature gradients are used to evaluate differences in forces that move moisture either as liquid or vapor (Miller and otl ors, 1961). Differences in soluble sodium percentage ard total soluble cations with depth in each soil profile are used to define recurring patterns and modes of mois ${ }^{\dagger}$ ure migration (Miller and Ratzlaff, 1961; 1965).

Experimental devices, designed to monitor changes in total soil-moisture stress and soil temperat ire, are $\mathrm{m}$ stalled under and adjacent to a selected clump of Tamarisk trees. These devices use electrical resistance-type vapor pressure sensors to measure soil-moi ture stress and thermistors to measure soil temperatures. The stress sensors are enclosed in individual chambers designed to expose them to the soil air but to preclude direct contact with soil or soil solutions. ${ }^{3}$ Periodic sampling

3 The effectiveness of these devices was impaired by pro'nnged flooding of the sites and the devices were destroyed during dredging operations in the river channel (McQueen and Miller, 1966). 
yields detailed information on stress gradients. The filter-paper method is used for measuring moisture stress lescribed by McQueen and Miller (1966) and by Miller and others (1961). Specially treated filter paper, which acts as a gravimetric moisture-stress sensor is inserted into cans containing soil samples. The samples are stored in the laboratory at constant temperature to permit equilibration of moisture between paper and soil. The moisture content of both the sample and the paper is then determined gravimetrically. The total stress is read from the calibration curve which shows the relation between water content and stress for the filter paper.

Some study sites have been relocated since the project began, but objectives and methods have not. The saltcedar site on the Gila River has been inundated but is still giving useful data under high water-table conditions. The cottonwood, willow, and mesquite sites on the San Carlos River have yielded satisfactory field data. Laboratory analyses of these soil samples are presently (1965) being made.

\section{THE ENERGY BUDGET FOR EVAPOTRANSPIRATION MEASUREMENT}

\section{By O. E. Leppanen}

The heat-energy budget method of measuring evapotranspiration is being applied at locations within the project area. The purpose is to estimate evapotranspiration typical of these locations by a method independent of the water budget and to compare the water loss in each reach as computed by the two methods.

The energy budget is a general method of determining evaporation and transpiration. If application to the Gila River Phreatophyte Project area proves successful it could be applied confidently to similar areas. Furthermore, testing of mass-transfer methods and fly-over remote sensing techniques will be facilitated by using the energy budget observations as a control.

The theory of the energy-budget method has been presented by several authors. A good general description of the physical variables which need to be considered has been given by Tanner (1960). The measurement of these variables in the project area is discussed in the following section.

The sun is the source of most of the radiant energy used in transpiration from plants and evaporation from the soil. Considerable solar energy is also reflected by plants and bare surfaces, particularly water surfaces. The amount of reflected radiant energy becomes significant when the sun is low in the sky. These surfaces become warmer by mid-day and reradiate more heat to the atmosphere as infrared radiation. Clouds and gases in the air, such as water vapor and carbon dioxide, also contribute significant amounts of heat to the surface and also receive heat from surface radiation.

Instruments called net radiometers measure the new flow of radiant energy through a horizontal plane located above the ground surface. These instruments integrate energy flows having wavelengths from the ultraviolet to the far infrared.

At night, transpiration usually decreases and the amount of heat stored in the vegetation bulk is small. Evaporation from soil may not change radically from day to night because the heat stored during the day becomes available to the damp soil at night. Water bodies store solar energy readily as evidenced by the gradual warming of lakes and rivers throughout the summer months. Most of this energy becomes available for evaporation from the water surface, sometimes at a later date or even many months later.

Heat flow into and out of soil can be evaluated in two ways. In the first method, heat stored at the end of a period is compared with that stored at the beginning. Thus, an integration of the heat flows is known if the heat capacity of the mass can be computed. The other way of determining heat flow is by direct measurement of the rate of flow using heat-flow plates and then integrating these measurements over a time period. The instruments used in this method are similar to the net radiometer that measures net radiant-energy flows. The time-rate of flow also may be approximated by temperature measurements made at several depths, which, when heat capacity and heat conductivity are known, allow computation by the classical methods of Newton and Fourier. Heat stored in water masses is generally determined by the change-in-storage method mentioned above, that is, by comparing average temperatures and water volumes at the beginning and end of a time period.

The vegetation, ground, and water surfaces constitute a system that exchanges heat with passing air. During the day large amounts of sensible heat are removed from the surfaces; this heat results in increased air temperature. Just before and after sunset, some heat may be withdrawn from the ambient air and utilized for evapotranspiration; this heat loss causes a noticeable cooling of air near isolated stands of vegetation. The measurement of these advected heat flows is, at present, one of the less accurate parts of the energy budget. Using recent data from the Buckeye Project, Ariz., for saltcedar growing in tanks (T. E. A. van Hylckama, written commun., 1966), it may be possible to modify the present methods of evaluation and improve the measurement of the advected heat flows. Because water use can be measured for periods as short as two hours, various micrometeorological theories may be tested for application over longer periods. 
The energy-budget method of measuring evapotranspiration has been tested by several groups of scientists, principally in areas covered by agricultural crops. The control methods applied to measure actual water use by the crops have been of varying accuracy, but most tests imply that the energy budget will give results accurate to \pm 20 percent when used on vegetated areas similar to those over which tests have been made. In a field test over alfalfa, for example, measurements from the energy budget and water budget differed by about 20 percent (Leppanen and Harbeck, 1960). From an analysis of unpublished computations by T. E. A. van Hylckama from the Buckeye Project, it was decided that the energy-budget method could be used over other vegetation, particularly tall bushy plant cover such as saltcedar. Measured water use in the tanks on the Buckeye Project and the use predicted from the energy budget agreed within 18 percent. The energy budget has only been used at single, reasonably homogeneous sites.

If it were not for the necessary micrometeorological measurements of temperature and water-vapor content above the surface, simultaneous measurements at many sites would not be difficult. Plans are to operate energybudget stations at three different sites for several months in order to sample various types of vegetation (fig. 10). Both average evapotranspiration during the operating period at each site and fluctuations of evapotranspiration within these periods will be related to measurements of hemispherical radiation, air temperature, and vapor pressure at a fixed station at Coolidge Dam. This fixed station also is used to determine evaporation from San Carlos Lake by energy-budget methods.

Considerable data are involved in energy-budget experiments. Transducers and recording instruments for the energy-budget studies allow automatic data processing. Paper tape suitable for electronic data processing is punched at the field site so that time lag between field observations and a usable evapotranspiration estimate will be minimal.

\section{SUMMARY}

By R. C. CULYar

Quantitative evaluation of water conservation by phreatophyte control requires that changes in evapotranspiration be measured or estimated. Because components of a hydrologic system are interrelated, a change in evapotranspiration, for example, can be expected to alter other parts of the system, such as the altitude of the water table. The measurement of evapotranspiration from a flood plain of a major river, before and after the application of phreatophyte control, was selected as the primary method of evaluating water

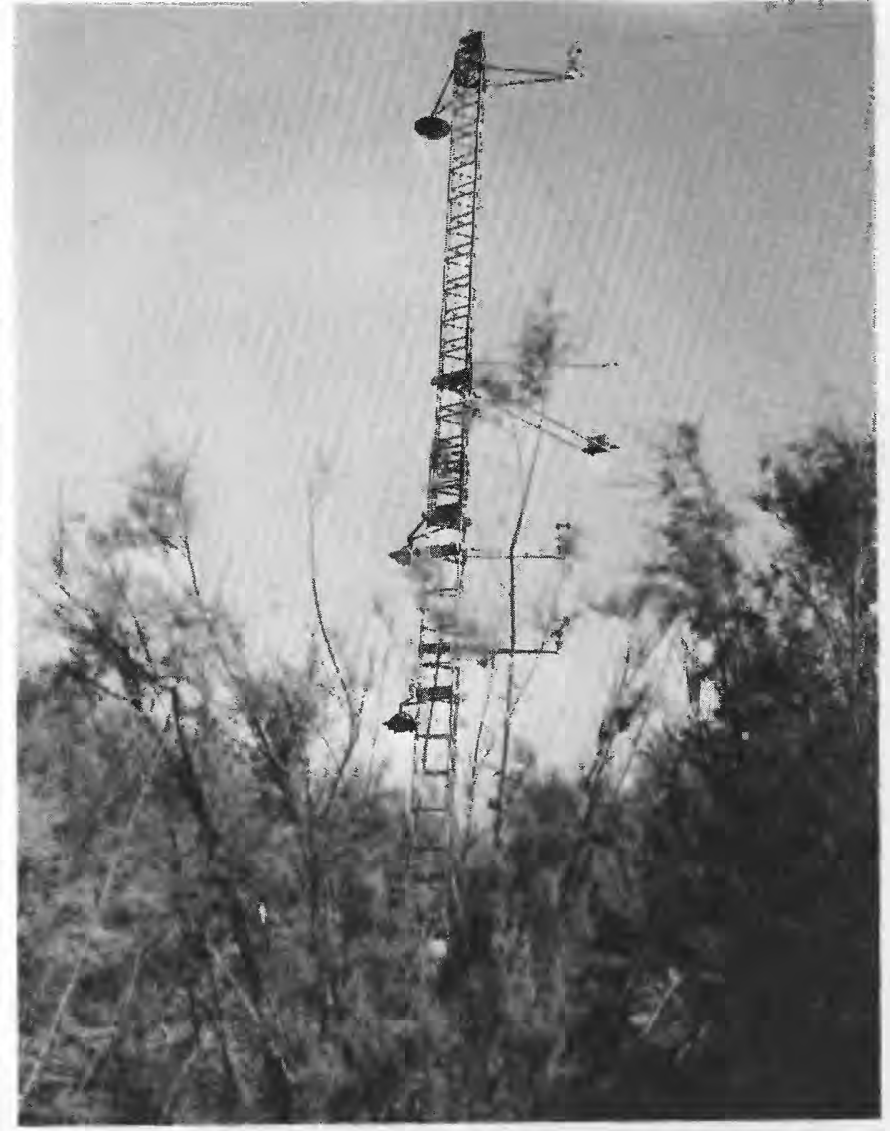

FIGURE 10.-Energy-budget station in operation at section 19.

conservation by phreatophyte control. A water budget is being computed in which evapotranspiration is the difference between the water inflow and outflow to a reach, adjusted for changes in storage. The energybudget method is being used to measure evapotranspiration from small areas on the flood plain. The results will give an independent evaluation of evapotranspiration.

The project area consists of a 24-kilometer (15-mile) reach along the Gila River west of Bylas on the San Carlos Apache Indian Reservation. It includes all of the flood plain and extends on to the lower terraces along the river. Three contiguous reaches along the flood plain are being used for this study. Each reach is about 8 kilometers (5 miles) long and contains about 800 hectares (2,000 acres) of phreatophytes. The flood plain is densely covered by phreatophytes, mainly saltcedar. The terraces are covered by less dense growths of saltcedar and by mesquite. The entire area is underlain by basin-fill deposits, which are fine grained and yield small amounts of water. Coarse-grained alluvium overlies the basin fill throughout most of the study reach. The alluvium forms the principal aquifer, and the phreatophytes obtain most of their water from it. 
The water budget will provide a measure of the quantity of water vaporized from water, soil, and vegetal surfaces during periods as short as 3 weeks. The quantity will be related to type of vegetation, meteorologic conditions, depth to water, and chemical quality of the ground water. Only the vegetal surfaces will be intentionally changed by phreatophyte control. Preclearing evaluation includes $1963-67$, and postclearing evaluation will continue through 1972 .

Four gaging stations have been installed along the Gila River, and 62 stations have been installed on tributaries. Water-level fluctuations are recorded in $72 \mathrm{ob}-$ servation wells spaced in lines of 6 wells, each extending across the valley. An access tube for a neutron soilmoisture meter is located adjacent to each observation well. Precipitation is measured in rain gages installed at both ends of each line of wells.

Many previously developed techniques are being used in this study. Innovations are being made in the application of techniques and in methods of computation.

\section{REFERENCES CITED}

Blaney, H. F., and Criddle, W. D., 1962, Determining consumptive use and irrigation water requirements: U.S. Dept. Agriculture Tech. Bull. 1275, 59 p.

Campbell, C. J., and Dick-Peddie, W. A., 1964, Comparison of phreatophyte communities on the Rio Grande in New Mexico : Ecology, v. 45, p. 492-502.

Daubenmire, Rexford, 1959, A canopy-coverage method of vegetational analysis: Northwest Sci., v. 33, p. 43-64.

Davidson, E. S., 1961, Facies distribution and hydrology of intermontane basin fill, Safford basin, Arizona, in Short papers in the geologic and hydrologic sciences: U.S. Geol. Survey Prof. Paper 424-C, p. 151-153.

Dorroh, J. H., Jr., 1946, Gertain hydrologic and climatic characteristics of the Southwest: Albuquerque, New Mexico Univ. Press, 64 p.

Fenneman, N. M., 1931, Physiography of Western United States : New York, McGraw-Hill Book Co., Inc., 534 p.

Gates, D. M., 1965, Heat transfer in plants: Sci. Am., v. 213, no. 6, p. 76-84.

Gatewood, J. S., Robinson, T. W., Colby, B. R., Hem, J. D., and Halpenny, L. C., 1950, Use of water by bottom-land vegetation in lower Safford Valley, Arizona: U.S. Geol. Survey Water-Supply Paper 1103, 210 p.

Hendricks, E. L., Kam, William, and Bowie, J. E., 1960, Progress report on use of water by riparian vegetation, Cottonwood Wash, Arizona: U.S. Geol. Survey Circular 434, 11 p.

Horton, J. S., Robinson, T. W., and MeDonald, H. R., 1964, Guide for surveying phreatophyte vegetation: U.S. Dept. Agriculture Handb. 266, $37 \mathrm{p}$.

Leopold, L. B., Wolman, M. G., and Miller, J. P., 1964, Fluvial processes in geomorphology: San Francisco, W. H. Freeman and Co., $522 \mathrm{p}$.
Leppanen, O. E., and Harbeck, G. E., 1960, A test of the energybalance method of measuring evapotranspiration: Internat. Assoc. Sci. Hydrology Pub. 53, p. 428-437.

McQueen, I. S., and Miller, R. F., 1966, Calibration and evaluation of a wide-range method for measuring moisture stress in field soil samples: UNESCO, Symposium on water in the unsaturated zone, Wageningen, Netherlands, June 1966.

Meinzer, O. E., ed., 1942, Hydrology : New York, Dover Publications, Inc., $712 \mathrm{p}$.

Miller, R. F., Branson, F. A., McQueen, I. S., and Culler, R. C., 1961, Soil moisture under juniper and pinyon compared with moisture under grassland in Arizona, in Short papers in the geologic and hydrologic sciences: U.S. Geol. Survey Prof. Paper 424-B, p. 233-235.

Miller, R. F., and Ratzlaff, K. W., 1961, Water movement and ion distribution in soils, in Short papers in the geologic and hydrologic sciences: U.S. Geol. Survey Prof. Paper 424-B, p. $45-46$.

1965, Chemistry of soil profile indicates recurring patterns and modes of moisture migration: Soil Sci. Soc. America Proc., v. 29, no. 3, p. 263-266.

Parker, K. W., and Martin, S. C.. 1952, The mesquite problem on southern Arizona ranges: U.S. Dept. Agriculture Circ. 908, $70 \mathrm{p}$.

Robinson, T. W., 1952, Phreatophytes and their relation to water in Western United States: Am. Geophys. Union Trans., v. 33 , no. 1, p. 57-61.

1958, Phreatophytes: U.S. Geol. Survey Water-Supply Paper 1423, $84 \mathrm{p}$.

1964, Phreatophyte research in the Western States, March 1959 to July 1964: U.S. Geol. Survey Circ. 495, 31 p.

1965, Introduction, spread, and areal extent of saltcedar (Tamarix) in the Western States: U.S. Geol. Survey Prof. Paper 491-A, $12 \mathrm{p}$.

Sellers, W. D., ed., 1960, Arizona climate: Arizona Univ. Press, $60 \mathrm{p}$.

Tanner, C. B., 1960, Energy balance approach to evapotranspiration from crops: Soil Sci. Soc. America Proc., v. 24, p. 1-9.

U.S. Department of Agriculture, 1962, Field manual for research in agricultural hydrology: U.S. Dept. Agriculture Handb. $224,215 \mathrm{p}$.

U.S. Geological Survey, 1961, Surface water supply of the United States, 1960, Part 9, Colorado River basin: U.S. Geol. Survey Water-Supply Paper 1713, $520 \mathrm{p}$.

[U.S.] Weather Bureau, 1964, Dicennial census of United States climate-Climatic summary of the United States-Supplement for 1951 through 1960, Arizona : U.S. Dept. Commerce, Climatography of the United States 86-2, 95 p.

van Hylckama, T. E. A., 1963, Growth, development, and water use by saltcedar (Tamarix pentandra) under different conditions of weather and access to water: Internat. Assoc. Sci. Hydrology, Pub. 62, p. 75-86.

White, W. N., 1932, A method of estimating ground-water supplies based on discharge by plants and evaporation from soil-results of investigations in Escalante Valley, Utah: U.S. Geol. Survey Water-Supply Paper 659-A, 105 p.

U. S. GOVERNMENT PRINTING OFFICE : 1970 O - 371-096 